\title{
Where Independence Meets Its Match: The Intersection of Musical Identity, Record Promotion and College Radio Programming
}

\author{
Aaron J. Hawley \\ West Virginia University
}

Follow this and additional works at: https://researchrepository.wvu.edu/etd

\section{Recommended Citation}

Hawley, Aaron J., "Where Independence Meets Its Match: The Intersection of Musical Identity, Record Promotion and College Radio Programming" (2010). Graduate Theses, Dissertations, and Problem Reports. 3305.

https://researchrepository.wvu.edu/etd/3305

This Thesis is protected by copyright and/or related rights. It has been brought to you by the The Research Repository @ WVU with permission from the rights-holder(s). You are free to use this Thesis in any way that is permitted by the copyright and related rights legislation that applies to your use. For other uses you must obtain permission from the rights-holder(s) directly, unless additional rights are indicated by a Creative Commons license in the record and/ or on the work itself. This Thesis has been accepted for inclusion in WVU Graduate Theses, Dissertations, and Problem Reports collection by an authorized administrator of The Research Repository @ WVU. For more information, please contact researchrepository@mail.wvu.edu. 


\title{
Where Independence Meets Its Match: The Intersection of Musical Identity, Record Promotion and College Radio Programming
}

By

Aaron J. Hawley

\author{
A Thesis \\ Submitted to \\ The Perley Issac Reed School of Journalism \\ At \\ West Virginia University \\ In partial fulfillment of the requirements \\ For the degree of \\ Master of Science \\ In \\ Journalism
}

\begin{abstract}
Sara Magee, Ph.D., Chair
Steve Urbanski, Ph. D.

Paula Fitzgerald, Ph. D

Rick Bebout, M.S.J.
\end{abstract}

Morgantown, West Virginia

2010

Keywords: College Radio, Record Promotion, Radio Programming, Music Director, Playlist, Gatekeeping 


\section{$\underline{\text { Abstract }}$ \\ Where Independence Meets Its Match: The Intersection of Musical Identity, Record Promotion and College Radio Programming}

\section{Aaron J. Hawley}

College Radio has long been championed for being one of the last independent voices on a radio dial dominated by corporate for-profit stations. While corporate stations program their playlists towards whatever is on the charts, independent programming has long been part of the appeal of college radio. However, college radio music directors are in constant contact with record promoters whose sole goal is to get their clients' records played on-air. While a notion of independence is central to college radio's musical identity, these record promoters hold a great deal of power in the decision making process. Upon investigation at WVU in the spring of 2008 and at WVU, Pitt and Washington \& Lee in the Fall of that year, it appears that contact with certain record promoters, as opposed to a record's own merits, are the key factor in whether that record would be included on the playlist. It was discovered that seven record promotional houses account for a disproportionate number of all albums received and played by the college radio stations and function as more of a gatekeeper to the airwaves than the music directors themselves. 


\section{Acknowledgements}

This Master's Thesis would never have been possible without the contributions of a great number of people. Dr. Sara Magee for chairing this project and being willing to put up with an uncountable number of delays in its completion. Dr. Steve Urbanski for his guidance in this project and the infectious enthusiasm he has instilled in the Master's Program here at the Pearly Isaac Reed School of Journalism. Dr. Paula Fitzgerald for agreeing to participate and continuing to participate despite the delays. Professor Rick Bebout for showing support and confidence in my abilities throughout the past year of delays. Rob Wehrle, Rupam Sofsky, Nathan Miller, Jesse Novak and Daniel Conway at WWVU for allowing me to interview them for this project and the independent study project which proceeded it. Without insights they gave into music selection and record promotion this project would never have been possible. Emily Tantillo at WPTS and Michael Morella at WLUR who agreed to participate in this project sight-unseen without ever meeting me in person. Finally to Kim Harrison and Alex Gavula at WWVU for allowing me the opportunity to work at U92 which provided me with my entrance into the world of radio, a career I hope continues for many, many years to come. 


\section{Table of Contents}

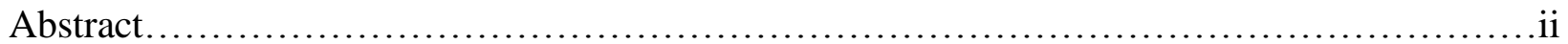

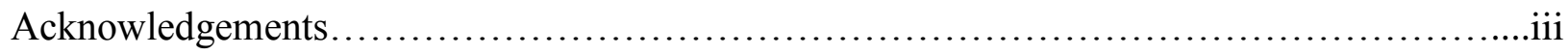

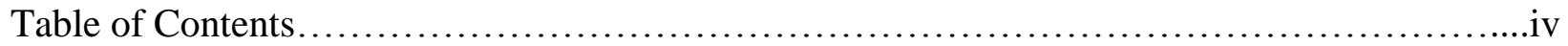

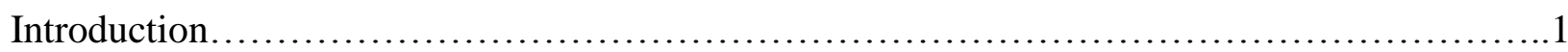

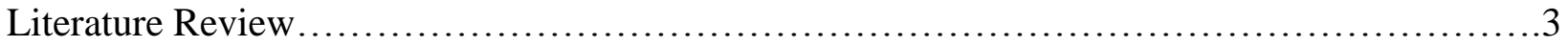

Research Questions....................................................................

Method............................................................................ 12

Chapter 1: WWVU-Only Study, Spring '08 Findings................................. 15

Chapter 2: WWVU-Only Study, Spring '08 Discussion............................... 18

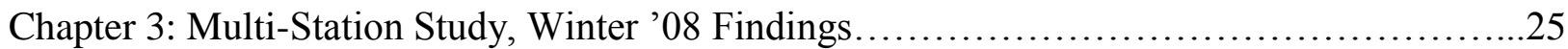

Chapter 4: Multi-Station Study, Winter '08 Discussion..................................33

Conclusion/Limitations for this Study ..........................................45

Future Research Implications..................................................48

Appendix 1: WWVU, Records Received/Inclusion Data, 11/15-12/15/08..................49

Appendix 2: WPTS, Records Received/Inclusion Data, 11/15-12/15/08...................52

Appendix 3: WLUR, Records Received/Inclusion Data, 11/15-12/15/08..................55

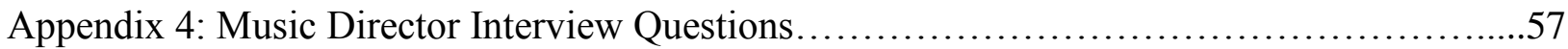

Appendix 5: Cover Letter for Data Collection Packet...................................58

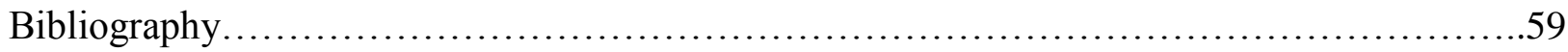




\section{Introduction}

One of the last bastions of non-computer generated music programming is college radio. Accounting for approximately $11 \%$ of the terrestrial radio stations in America (Wall, 2007), college radio still plays an integral part in the taste-making of the traditional music industry. At most college radio stations the process by which music is selected is a much more hands-on process than at major commercial radio stations. The mainstream music industry is paying close attention to the decisions made by college radio station music directors because they can often be used to predict which artists could be lucrative money makers for major labels in the future.

College radio prides itself on existing outside the mainstream music industry, bridging the gap between struggling artists and large mainstream music corporations. College music directors take great pride in the albums they choose to include on their playlists, and in interviews seemed to staunchly defend the notion of their station existing outside the music industry mainstream. They take into account a variety of factors when deciding what music is right for their station, but that isn't always the only factor. Oftentimes the outside contact that they have with the promotional companies that are hired by artists or record companies has a dramatic impact on what is included or excluded from airplay.

An independent research project at West Virginia University's radio station, WWVUFM, in Spring of 2008 revealed the importance of this relationship between the record promoters and the music director. Contact with a promoter was revealed to be the defining factor between a record being included in the station's rotation. Interviews with four current and former WWVU 
music directors stressed this relationship and statistics backed this assertion up. In this study it was shown that seven promotional firms, representing $12 \%$ of all promoters that WWVU worked with, accounted for $71 \%$ of all of the records placed into rotation during the time period researched. There was nothing more important than the relationship between the music director and the record promoter (Hawley 2008). The outcome of this study seems to suggest that the primary factor in whether or not a record receives airplay is not tied to what style or genre the release is but instead, the deciding factor is often what promotional support the record is receiving from the record promoters. The same record, sent independently, seems to have a harder time getting airplay than if it had been sent from one of the industry's large college radio promotion companies.

The goal of this Master's Thesis is to examine the role of the college radio music director and attempt to assess the influence that record promoter have on the addition of music to the station's playlist. It seeks to prove that record promoters. Not just genre or style, are the most influential factor in determining whether or not a record is added to the playlist at a college radio station. By repeating this study at other college radio stations within the same region I hope to prove that record promoters have great influence over the gate-keeping of college radio music directors. Hopefully a closer examination of this relationship will benefit both music directors and record promoters alike by allowing each to understand the dynamics in the decision making process of college radio's gatekeepers, which is a critical factor in the ongoing discussion of the independence of college radio. 


\section{Literature Review}

\section{Gatekeeping}

To accurately discuss the forces that affect the music selection process in college radio, we must examine the scholarly research currently available on the subject. Gatekeeping, the media theory tied most closely to my research, is discussed in a number of journal articles. Stephen Reese and Jane Ballinger (2001) discuss the history of gatekeeping in their article "The Roots of a Sociology of News." The authors scrutinize two classic studies that helped coin the term: David Manning White's “The Gatekeeper" (1964) and Warren Breed's "Social Control in the Newsroom.” (1964) These studies, which helped introduce gatekeeping, provide the foundation for further research and thinking on the subject.

These studies first addressed the social control that is exerted by those in the newsroom in regards to what would be included as news. They also pointed out that the general public takes for granted that news outlets have their best interest in mind and are not pursuing their own private interests regarding what is included and excluded in that day's news. This is the same power that a music director wields at a college radio station, constantly assessing what is to be included, and what is to be excluded.

The forces that affect these decisions are examined more in depth in the study of gatekeeping titled "Individual and Routine Forces in Gatekeeping" (Shoemaker, 2001). The study asserts that there are a wide variety of forces that can influence whether or not an item is included. These forces are individualized or institutionalized. Individual forces would be those controlled by the individual within the organization, such as a political bias or lack of knowledge on a certain subject. Institutional forces would be those routines and policies that occur within a 
media organization that could be used to preclude certain items to reach the media consumer. Examples of individual gatekeeping in radio could include taste issues, while institutional gatekeeping could be the relationships the station has with various record promoters. Each individual item (in this study's case, an album) has a different distance to travel before it reaches its desired destination: airplay.

\section{College Radio Programming}

To apply the gatekeeping theory to a study of college radio programming it is also imperative to address what other current studies have examined college radio playlists. Desztich \& McClung's (2007) study "Indie to An Extent? Why Music Gets Added to College Radio Playlists" and Tim Wall's (2007) "Finding an Alternative: Music Programming in US College Radio" both attempted to answer the same question, though they both came up with differing answers.

Using the Theory of Planned Behavior, Desztich and McClung (2007) surmise that college radio is still distinctly tied to the music industry. They describe it as being unique because it is a field where "independent decision making and expression can meet traditional business models." (Desztich \& McClung, 2007, p. 209) The authors cite evidence that they claim supports the notion that despite the music directors stating otherwise, that the record companies have a great influence as to what gets put on the air. They deduce that the only positive predictor towards what is included is record company promotional material coupled with obscure and unique music. The final conclusion is that despite college radio's culture being steeped in independence, difference, and exclusivity, record companies are a big part of the 
equation as well. That is why the authors concluded that the radio stations were independent, but only to an extent.

Tim Walls' (2007) case study of three prominent college stations in the northeastern United States came to a different conclusion. Walls found that the progressive mission of early college radio stations is still alive and well today. He also states that the notion of "alternativeness," which is upheld by each station, has its roots in the countercultural movement

of the 1960s. He deduced that despite little recognition of the work of their forbearers, almost all he interviewed still retained the core values of the earliest pioneers of college radio. Wall's three studies uphold their independent views although in different programming decisions. He concludes that music radio is an under researched field that needs much more study.

\section{Promoting Music}

But how does that music make it to the radio stations in the first place? Often it is sent as part of a large record company's promotional campaign, other times it is smaller independent labels that cater to college radio specifically, or independent artists who handle their own promotions. Understanding the system that supplies radio with its content is an integral part of understanding what makes it on the air. Keith Negus' article 'Plugging and Programming: Pop Radio and Record Promotion in Britain and the United States" (1993) helps us understand that system. Though outdated- Negus' article was published in the pre-internet days of the early 1990s- it still offers great insight into the system of promotion that record companies rely on to publicize their product. Though the means of contacting radio stations and distributing their 
product may have changed with the advent of the World Wide Web and mp3s, the goals of the record companies remain the same.

Getting a song airplay, from a record company's standpoint, is rarely the final goal. As with all businesses, record companies are focused on increasing sales. Getting positive airplay allows them to achieve this goal. Peter S. Fader and Wendy W. Moe's article, "Modeling Hedonic Portfolio Products: A Joint Segmentation Analysis of Music Compact Disc Sales” (2005) shows the lengths to which record companies will research in order to better market their music. The basic premise is that several generic consumer bases exist in the music industry and remain fixed across all genres. By successfully marketing to a small percentage of each of these customer segments and accelerating the pace, when successful, a record company should be able to successfully sell its product. The authors applied their theories to twenty different albums and discussed the effects of variables, such as time of year and radio airplay.

Though Fader and Moe's study applies primarily to the mainstream record industry, one of the fundamental characteristics of college radio is the notion of independence and alternativeness. These factors have an important impact on what those in college radio surmise to be "their music." However, there are a number of independent record labels that cater exclusively to college radio. Two of the most influential independent record labels are examined in Hesmondhalgh's "Post-punk's Attempts to Democratise the Music Industry: The Success and Failure of Rough Trade" (1997) and Stephen Lee's article "Re-examining the Concept of the 'Independent' Record Company: The Case of Wax Trax! Records” (1995).

In each article the author provides an interesting glimpse into the history, failures and successes of each label. Though both would eventually fold (and be purchased by a larger record 
company) each would adhere to an independent ethos that affected most, if not all, company decisions. In each event the notion of artistic autonomy and a shared culture was paramount to producing, distributing and profiting from a specific product (i.e. an album or band). These record labels also had a small promotion and distribution budget and had to select their targets carefully, lest the entire promotional push be a financial disaster. Because of this, and the openminded nature of college radio, the two were intrinsically tied together. The independent record companies received a higher rate of success on college radio, and college radio continued to keep their playlists out of the mainstream.

\section{Musical Identity}

Why do college radio stations take more of their identity from the music they select, whereas mainstream radio stations seem content to play "the hits" which leaves them identical to every other top-40 radio station out there? A hint can be gleaned from Theodore Gracyk's article "Romanticizing Rock Music" (1993). This article discusses the aesthetic merits of rock music and how it impacts the listener. The independent music that dominates college radio playlists inspires devotion from its fans that cannot be found anywhere else across genres. Though the number of albums sold may pale in comparison to the major labels, the purchasers of those albums feel much closer to the music than in other genres.

Despite the attachment college radio music directors and listeners may have to what they describe as "their" music it is imperative to understand what outside influence the mainstream media has on value-making. By looking at two previous studies we can begin to understand the weight and influence that media sources hold. Two studies, "Star and a Half: A Critique of Rock 
Criticism in North America" (McLeod, 2001) and "Counting Down to Number One: The Evolution of the Meaning of Popular Music Charts" (Hakanen, 1998) analyze the media's specialized role in processing meaning for popular music. Hakanen concludes that the Billboard music charts create value and meaning for what is an otherwise intangible product. Despite most readers' knowledge that the charts are strictly calibrated with sales figures, they rarely cite sales as an important variable in selecting the music they wish to listen to. However, most people want to be "in the know" so they place an intrinsic value upon what they believe others might be listening to.

McLeod's study shows how in order to enter the arena of rock criticism one must have a particular cultural knowledge that gives weight to his or her opinions. Without this nicheintelligence one cannot survive as a critic, and likewise one cannot succeed without a near constant reminding of their readers that they do not possess this cultural capital. McLeod comes to an important conclusion in his paper that rock critics do not exist in a vacuum. Instead, they are part of a larger network within the music community that contains college radio, record label publicists and executives, bands, fans and collectors. Most important is his assertion that critics "articulate the attitudes of these communities, and they also influence them. Most importantly, the very nature of their profession positions them as key figures in maintaining the circulation of the discourses discussed in this essay" (McLeod 2001, p. 59). Put simply, their influence on other sectors of the music industry is too important not to study. 


\section{The Future of College Radio}

Finally, one must address what the future may hold for college radio (and independent media in general). R. Wilfred Tremblay's article “A Delphi Study on the Future of College Radio" (2003) polled 13 college radio advisors and attempted to answer that question. Tremblay came to five conclusions. First, he concluded that there is a decreasing prestige of college radio advising within academic communities. Second, there has been a decrease in the amount of financial support offered by overseeing institutions. Third, there is a technical change in the way radio is being produced, relying more on digital production and transmission. Fourth, the demographics of the students who participate is undergoing a shift. Finally, there will be more reliance on locally produced music and sports programming. Do these spell doom for college radio? Probably not, but this is reflective of another way media is changing with technology.

\section{Conclusion}

As shown, there has been scant research done into the record promotion and radio programming process and there still is a great deal to be learned. By examining the relationship between college radio programmers and record promoters we can better understand the dynamics at play when new music makes it to the airwaves. We can better understand the gatekeeping role played by college radio music directors, and how it is influenced by the musical identity of college radio as a whole and how it intersects with the mainstream record promotion industry. It is these forces, and the influence of record promotion as a whole, that can allow us to better understand the way college radio is programmed. 


\section{$\underline{\text { Research Questions }}$}

This thesis examines the role of the college radio music director and attempts to assess the influence that record promoters have on the addition of music to the station's playlist. While college radio is primarily defined by a musical identity rooted in independence, an examination of this process will show that outside stimulus, in the form of record promoters, wield a great deal of influence in the decision of what music does and does not make it to the airwaves. In order to better illuminate this relationship the questions that must be addressed are:

RQ1: Does the relationship between a record promoter and a music director have an influence on music being included into a station's playlist?

RQ2: What role do record promoters play in the music selection process?

RQ3: Could music directors do their jobs without these record promoters?

The researcher hopes that if these questions can be adequately addressed, then some light can be shed on the influence the record promoter has on the music selection process. A clearer understanding of this relationship will benefit both music director and promoter alike by acknowledging the forces that are at work as college radio is being programmed. For the music directors, there is a benefit to acknowledging this influence to allow them to conscientiously decide what music is suitable for play. From the standpoint of record promoters, it would be valuable information to know how the decisions that they are attempting to influence are being made. As college radio takes much of its identity from its presumed independence, an examination of college radios place within the greater music industry is both needed and relevant. 
Each of these research questions supports the intended research goal of understanding the influence of record promoters in the playlist programming process of college radio music directions. RQ1 and RQ2 seek to clarify the role and influence of the record promoter in supplying the music director with new music and the influence the promoter has in the programming of the director's station. RQ3 is to qualify if there are other potential ways for music directors to receive and seek out new without contact with the mainstream record promotion industry. 


\section{Method}

Data was collected to address these research questions in a three step process. The first step was to recruit college radio stations in the region to participate. In order to create a large enough sample for the purpose of this project, the researcher gathered data at four universities. Ten stations were targeted to assist with this process, and those stations were contacted (see Appx. B). Initially four stations agreed to participate, WWVU at West Virginia University, WPTS at the University of Pittsburgh, WLUR at Washington \& Lee and ACRN at Ohio University. However, of the four stations that agreed to participate, only three returned their data packets, WWVU, WLUR and WPTS.

The second step in the research process was conducted simultaneously at WWVU, WLUR and WPTS. At each station the music director logged all music received during the course of one month. The selected month of music logging occurred between November $15^{\text {th }}$ and December $15^{\text {th }}$, 2008. Music directors listed all releases they received at their radio station. Since most college stations add complete albums to rotation and then let their DJs select tracks from within each, only album information was gathered. The following data was gathered on each album received:

- Artist

- Album Title

- Record Promoter

- Date Recieved

- Inclusion Data

Inclusion Data refers to not only if the album was or was not selected for inclusion on the playlist, but also where in rotation the music was placed (see Appx. C). Many stations, like 
WWVU, use a tiered rotation system with releases being added to three categories Hots (receiving the most plays), Mediums (less plays than hots, but still prominent) and Lights (least plays of all). It was revealed in previous research at WVU that where in rotation an album is placed is of as much interest to a promoter as whether it made it in or not. (Hawley 2008)

As data was collected, it was sorted by promoter in order to see which promoters were the most successful in getting their records played. By examining this information at multiple stations, we can see if the same promoters were successful at every station. The purpose is to illuminate which promoters were successful in influencing the music directors' record selection process.

For the final step of the process, completed after record inclusion data had been collected, each music director was interviewed about their job, their station, their musical preferences and their relationships with record promoters (See Appendix C) These interviews play a crucial role in understanding the data collected by allowing music directors to clarify their thoughts and motives, this puts the playlist programming data in context and creates a better understanding of the music selection process. Reconciling the record selection data with why music directors chose them also contributes to the understanding of the success rates of various record promotion companies.

It was determined that the researcher would not interview the record promoters themselves for this study because it was their influence that was being examined. The researcher did not feel it necessary to ask them if they were attempting to influence the record selection process because that is at the very heart of their job description. Since their success or failure would be determined by whether or not they could get their clients airplay, it seemed redundant 
to ask them if it was their goal. While record promoters exist in the for-profit would of the mainstream music industry, it does not apply to this study. To broaden the scope of this study in future research endeavors, record promoters could be contacted, but they are not necessary at this time. 


\section{Chapter 1: WWVU-Only Study, Spring '08, Findings}

The impetus for expanding this study beyond West Virginia University came upon completing a WVU-only study in the spring of 2008. This study was the foundation for this thesis' expanded research conducted at Washington \& Lee, University of Pittsburgh and West Virginia University in the winter of 2008. The preliminary study seemed to suggest that promoters played a very influential role in the programming of otherwise "independent" college radio stations. That study is presented below in order to lay a foundation for the expansion that will occur in the thesis itself.

\section{WWVU-FM, West Virginia University, Morgantown WV}

WWVU-FM broadcasts at 91.7 on the FM dial in Morgantown,WV. Known more informally as U92, the station broadcasts at 2600 watts and has been on the air since 1982 . U92 also broadcasts a live stream on the web at u92.wvu.edu. U92's mission statement says it is "a non-commercial, educational radio station dedicated to serving both the WVU and Morgantown communities as a teaching and training facility, while at the same time providing alternative programming to our listeners" (u92.wvu.edu).

U92 broadcasts unique and diverse programming 24 hours a day, 7 days a week including regular rotation, consisting of alternative music selected by the music director, specialty shows which are hand selected by their respective hosts, and sports and news programming. In 2007 the station was nominated for station of the year by College Music Journal, college radio's premier industry journal.

The station is staffed by one general manager, one administrative assistant, numerous student directors and student volunteers and is located in the Mountainlair, the WVU Student Union, on the downtown campus of West Virginia University. Interviewed for this project were: 
music director Rupam Sofsky, assistant music director and music director-in-waiting Daniel Conway, metal director and 2008 CMJ Specialty Director of the Year (Heavy Metal, No Remorse).and Jesse Novak.

Rotation at WWVU consists of Hots, played 4 times hourly, Mediums, played 3 times hourly, and Lights, played 2 times hourly. WWVU also reports it's 5 offical monthly adds to College Music Journal.

\section{Record Inclusion/Exclusion Data Findings}

During the period stretching from March $15^{\text {th }}, 2008$ to April $15^{\text {th }}, 2008$ WWVU-FM at West Virginia University received a total of 260 different albums. Those albums were sent from 55 different promotional companies, with 34 albums being sent directly from record labels and artists. Despite being sent from such a vast variety of sources, 142 of the 260 albums were sent from seven different promotional companies. Those companies were Advance Alternative Media (AAM), Planetary, Team Clermont, Terrorbird, Spectre, Powderfinger and Pirate. Those 7 represented $12 \%$ of the total promotional companies in contact with the radio station during this period, but they also represented 54\% of the total albums received.

During the same period, 76 of the 260 albums were placed into rotation at WWVU, 24 albums in Hot rotation, 30 albums in Medium rotation, and 22 in Light rotation. 72 of those 76 albums were sent from 17 different promotional companies (4 had no promotion), with 54 of those albums coming from the seven large promotional companies. Those seven companies represent $71 \%$ of all of the albums placed in rotation during that period. Of the remaining 48 promotional firms, once the "big seven" are removed, only 9 promoters got a record placed into 
rotation. Of the 76 albums placed into rotation 4 were sent independently of an outside promoter and only 1 came from a record promoter that only sent one album. These four albums represent a mere $5 \%$ of albums placed into rotation and only approximately $2 \%$ of the total records received. Interestingly enough, those four independently promoted records were new releases from The Raconteurs and Black Keys, two bands with enough mainstream success to allow them to eschew the record promotion process, Anti-Flag; a Pittsburgh punk band with whom station personnel are very familiar; and Todd Burge a West Virginia singer songwriter with close ties WWVU. None of the independently promoted albums were releases that were new discoveries by the music director. Two of them, The Raconteurs and Black Keys, were high-profile national releases, while the other two; Anti-Flag and Todd Burge, were local releases without need for an outside record promoter due to strong ties to WWVU-FM

Despite an atmosphere of independence and alternativeness that permeates WWVU and the music it plays, data collected points to the importance of record promotion in that process. The assertion by WWVU music directors in interviews conducted for this study, that the record promoters play a hand in which albums go into rotation is an understatement. Seven companies dominated the releases placed into rotation during the time period of this study. It can be concluded that without this major record promoter support some, if not all, of these records would have had a harder time being put into rotation. College radio currently enjoys more freedom from a handcrafted music selection processes than mainstream radio. This study shows, however, that college radio stations are far from independent of the music industry as a whole. In fact, they are an integral part of it. 


\section{Chapter 2: WWVU-Only Study, Spring '08, Discussion}

The completion of interviews with WWVU music directors revealed two key factors played a major role in the selection of music for the station. The first was a mutually agreedupon but never explicitly stated definition of what music fit their idea of what should be played at an alternative, independent, college station. The second mitigating factor was the working relationship between the music director and the record promoters. Responses in the interviews were then reconciled with data collected on playlist additions to make any conclusive statements.

Interviews opened by asking each interviewee to describe the job of the music director at U92 and were uniform. The music director at U92 is entrusted with overseeing the music that is included on the station. They receive dozens of packages from record promoters each week and are charged with the task of listening to each, and deciding which albums should be included into WWVU's Hot, Medium, and Light rotation. The rotation is designed so more Hots (4) are played each hour than Mediums (3) or Lights (2). An album in Hot rotation can be heard on WWVU up to four or five times a day, while a Light rotation album may only get played once every two days.

Additionally, the music director keeps weekly office hours in which he or she receives phone calls from a variety of record promoters who inquire as to which of their albums have been added to the playlist. Also, WWVU reports five added albums to the College Music Journal (CMJ) each week, along with the stations top 30 albums. This data is collected by CMJ and distributed throughout the music industry. Inclusion on each of these lists is the primary objective of nearly all of the record promoters the music director works with. When compiled by $\mathrm{CMJ}$, these charts represent a kind of "early warning system" for the mainstream record industry. 
Success on the college radio charts can often come as a precursor to success in mainstream mediums such as Top 40 radio, television commercials and movie soundtracks.

While some stations adhere to a rigid, genre-defined, format such as Country, R\&B, or Oldies, WWVU simply stands by their station descriptors of "The New Music Pioneer" and "Morgantown's Only Alternative". Though each music director noted that they bring their own tastes to the table, favoring certain types of music over others, they all agreed that for inclusion on WWVU there are certain characteristics that must be present. Music that should be included on WWVU was described by the music directors as "against the grain," "left of center," or "music that hasn't hit the mainstream yet or at all." Upholding a sense of newness and being on the cutting edge was very important to the music directors. Replied one, "I think as the new music pioneer we should not only be playing the newest music available, but also music that's new in the sense of it's somewhat doing something different."

A reoccurring analogy that arose in three of the four interviews was that of a young person who did not have access to the types of music that WWVU plays. One music director replied, "I think college radio should be about, in a sense, fifteen year old kids sitting in their rooms and listening to the radio station and getting excited about hearing things that they've never heard before."

Additionally, the placement of a band within the landscape of the music industry played a key role as to whether their music should be included or excluded. One director responded, "I don't think that we should crossover too much into what commercial radio is playing." While another stated that a big factor in his selections was “that this band doesn't need our help. So if they're selling enough records on their own without us, or people already know about them... 
then that's something I don't feel like we really need to be doing here because it's already being done a lot of other places." The exclusion of the new record by major-label rock act Counting Crows during the data collection period upholds this notion. Despite the music of the Counting Crows sharing many similarities with music included in rotation, they weren't deemed a proper fit for WWVU.

This mutually agreed upon definition of "alternativeness" was not something that each music director pulled out of thin air. Instead it is a notion that some of them had been forming over a number of years, both at WWVU and prior to their starting at the station. One music director said they "each have [their] own different tastes but I definitely think there's a 'U92 aesthetic' that's run through each music director, regardless of our own personal differences." Another responded that his definition of what should be included on college radio was something he'd been thinking about for years, "being a fan of college radio and being thirteen, fourteen, sitting in my room with a little radio and tuning into the University of Pittsburgh and Carnegie Mellon and IUP's stations and just listening to it and understanding it. Knowing it should be something that's independent and unique and should reflect things that are bubbling up in terms of popularity and not necessarily things that have already blown up."

Also, the music directors acknowledged their decisions not being made entirely on their own and their awareness of the preferences of the other DJs at WWVU. One music director responded that he tried to keep, "music in rotation to make everybody happy." Another responded that he tried to be aware of "what other people are excited about. For instance, The Sword, which is a metal band. I like some heavy stuff but I'm not too into The Sword but since I know some people in town are excited about it, it's in heavy rotation and we're playing it a lot." 
While the music directors clearly indicated that they are not alone in the selection process, responses also pointed to another major player in the selection process: record promoters. The first interview question to elicit mentions to the importance of the record promoters was whether or not the music director would include an album in rotation if it didn't meet the subjective criteria of what belongs. Each responded that in certain situations they would include the album as a favor to a record promoter who has treated them well. One music director said he would place something in rotation that he didn't feel belonged in order to, "placate some promoter, or to help them out. You are trying to maintain a relationship with them. Sometimes you have to do things you don't want to do." Other responses showed that sometimes a music director would let the promoter think that something had been placed in rotation. "Sometimes I'll say it's in lights when it's not," replied one music director.

When asked how important the record promoters were to music selection all the music directors agreed that they are a major part of the process. They also responded that the relationship was mutually beneficial to all parties. One responded that, "you try to help them out, and they help me out with things, whether or not it's getting tickets to shows, or free CDs, or hopefully references." He also pointed out that "it is their job to maintain fifty percent of that relationship as well."

The record promoters will use plenty of incentives to build a relationship with the music director. One responded, "after CMJ [The annual music conference hosted by College Music Journal] I was taken out to some really, really expensive lunches and dinners, one that I was uncomfortable with how expensive it was. Now I feel like I'm kind of indebted to this dude." One music director pointed out that despite this pressure, it was still important to have the station's goals in mind at all times. "You just kind of have to know when to say no and you have 
to know when your standards are being pushed too far to the limits that you want to have," he replied.

While a tight relationship with a record promoter may give that promoter a slight edge, no relationship with any promoter could doom an album's chances of inclusion at WWVU. One music director responded that if he gets an album from someone he's unfamiliar with, "it would take me weeks to get to it." Another responded, "If I don't have a good relationship with someone and they send me a shitty record, then I'm not even going to listen to it and I'm just going to toss it out and I'm not going to think twice about doing that. If I have a good relationship with someone then I'll at least consider playing something."

Another music director pointed out that the big record promoters take up the bulk of their time, and the little promoters can get lost in the shuffle. He responded that it is, "a matter of there being a few 'flagship' promotional companies that definitely get the most attention. If someone sends me a record from Idaho and there's no promotional company and I put it on and I'm like 'this is alright' but I don't feel any pressure and if it's not groundbreaking, what's really the incentive for me to give it all this attention, you know?" In some ways, it seems that the independent notions of alternative music can be usurped by the importance of the mainstream record industry.

When pressed as to whether or not they saw this process of adding albums changing in the future, the music directors agreed that it is a process that is currently changing with the advent of new technology. In an effort to minimize cost many promoters are now distributing their albums online, and pointing music directors towards a company website. This is a trend not entirely welcome among the music directors. "It actually makes the music director's job more 
intensive and a lot more involved," responded one interviewee. "They're not just getting a CD in the mail, opening a package and taking it home. They're sitting at computer, downloading the record, and then downloading the artwork, listening to it, and then if they like it, they burn the CD and put it together."

Despite feeling that this technological change adds quite a bit of work to their jobs, the music directors understood the promotional company's motives. "I can definitely see why they would do it that way, because it's a lot easier to just post a record online and ask music directors just to download it than it is to go through and mail out five hundred or six hundred CDs to radio stations across the nation," responded one music director. Another understood, although only begrudgingly so, 'I'm against change for awhile, but then after the change happens I say it's maybe for the best. Right now as music director it's real difficult dealing with digital promotion, but it may be for the best."

As one explores this dichotomy between music selector and music promoter, a reoccurring question one must repeatedly ask is: who is more reliant on the other? Promoters need their music played, and music directors need music to play. Who has the upper hand? Responses were mixed. Could college radio survive without music promoters? One director replied, “I think in today's digital sendspace-album leak-age, I think that's totally possible. We couldn't be playing as many records as we are doing right now... but you know, anything is possible in this day and age." Another did not think it would be possible because they wouldn't be able to get the music in advance and it would affect the station playing the newest and most cutting edge music. "There's no way I could have done the job and kept it to such high standards without the music promoters. I might have been able to find other music but we wouldn't have 
been getting the Yeah Yeah Yeahs record before they hit mainstream, we wouldn't have gotten different records before they hit the mainstream."

As is clearly shown, a few select music promotion companies play a huge role in determining which records make it onto the air. They supply more records than all the other competing promoters combined, and they have a much more dramatic success rate in getting their records included in the playlist. In addition the constant contact between record promoters and the music director drives much of the selection process. WWVU music directors stated repeatedly that they were willing to be influenced by their relationship with certain record promoters.

While it seems that record promoters wield a great influence in which records are selected for play at WWVU, it cannot be surmised that this is the case at all college radio stations. In order to make better conclusions about college radio as a whole, this experiment will be expanded to other similar Universities in the region. With data is gathered from multiple sources we can draw better conclusions about whether this is commonplace throughout the entire spectrum of college radio or if undue influence held by record promoters is only present at WVU. 


\section{Chapter 3: Multi-station study, Winter '08 - Findings}

\section{Station Profiles and results}

While the Spring WWVU-only study showed the great influence that a small number of large promotional companies had on WWVU's playlist, it could not be surmised whether this was common throughout the rest of the college radio industry. For this reason, the scope of this study was expanded to include, along with WWVU, WLUR at Washington \& Lee University and WPTS at the University of Pittsburgh. The results will show that the influence of record promoters in college radio programming is not merely an isolated occurrence at WWVU, but commonplace throughout all of college radio.

By understanding this we can better examine whether the independent musical identity of college radio is compromised by contact with the mainstream record industry. More information on this dynamic would be of great value and relevance throughout all reaches of the music business. Since college radio prides itself greatly on it's own independence, it would be valuable to acknowledge the forces at work in playlist programming. On the other side of the fence, it would be of great value to record promoters to understand better the decisions being made which affect whether or not the music of their clients will be included for airplay.

\section{Record Inclusion/Exclusion Data}

For the second study, conducted from November $15^{\text {th }}$-December $15^{\text {th }}, 2008$ several things had to be taken into consideration and adapted. First, fewer records were sent during that period. While WWVU collected 260 records in the spring data collection period, they only received 124 records in the winter data collection period. This drop off of approximately $50 \%$ can be attributed to the cycles of the record industry that focus on the summer as a key time to promote 
new music. The collection period of November $15^{\text {th }}$-December $15^{\text {th }}$ had significantly fewer records included because it was slower period for record labels and promoters.

The second thing that needed to be considered was that Powderfinger Promotions sent a total of 1 record during this collection period. Therefore, they were removed from the list of major promoters. In the second data collection period the "Big Seven" were revised to now include Tinderbox Music along with Advance Alternative Media (AAM), Pirate Promotions, Planetary Promotions, Spectre, Team Clermont, and Terrorbird Promotions.

The dominance of these seven promotional companies is apparent in this study. Despite representing merely $12 \%$ of all promoters/record labels that the music directors dealt with they represented 53\% of all records received during the study period. Additionally, the "Big Seven" were responsible for $63 \%$ of all records that were included for airplay. It should be noted however, that the "Big Seven" also were responsible for $50 \%$ of all records passed on during the study period. This is in correlation with what was found during the first study at WWVU.

The success of these firms is also out of line with the smaller record promotion companies. Of the "Big Seven", only Planetary and Tinderbox had a less than $50 \%$ overall success rate across the three stations. This was mostly due to WWVU that received, and rejected, the largest number of records in the study sample. The large number of records sent by Planetary and passed on by WWVU skewed their sample to a less than $50 \%$ success rate.

Whereas most small promoters sent only a few records, and had a small percentage of success, these seven promoters were significantly more successful. This implies that if you are a musician and want your music on the air, you have a much better chance of success if you use one of these seven promotional companies to promote your record. The findings of this expanded study correlate with the findings of the earlier WWVU-only study. The records 
promoted by a select group of powerful promotion houses are added to the playlist with a much greater rate of success that those not promoted by the "Big 7". In addition, a greater percentage of the total records added to the playlist during both studies came from the "Big 7" than from all the other promoters combined.

\section{WLUR, Washington \& Lee University, Lexington VA}

WLUR is a 175 -watt non-commercial educational radio station owned by Washington \& Lee University and operated by the Office of Communications, and broadcasts at 91.5 on the FM dial in Lexington, Virginia. WLUR is staffed by Washington \& Lee students and members of the local community. The station broadcasts a wide variety of music along with public affairs programming, news, commentary and Washington \& Lee athletic events. The volunteers are supervised by a full-time general manager and various student managers. WLUR's mission statement is "to serve as an outlet for creative expression for members of the Washington and Lee community and to be a reliable source of entertainment, information and culture for the extended University community and Lexington area residents.”

Founded in 1966 as a 10-watt radio station and educational teaching tool by journalism professor Tom Riegel, WLUR has gone through a number of changes throughout its history. By the mid-1970s the station's broadcast power was increased to 175-watts, and the stations focus shifted from news writing and reporting to music and entertainment. In 1992 the university discontinued its radio journalism courses and the station became entirely an extracurricular activity. In 2001 WLUR went silent while it was transferred from the Journalism Department to the Office of Communications, and in 2002 the station began broadcasting again, for the first time under the charge of a full time director provided by the University. The station was 
completely restructured in regards to facilities, organization and programming. In 2007, WLUR began broadcasting 24 hours a day with the addition of BBC News and NPR Talk programming, a service of WVTF public radio in Roanoke, VA. These syndicated programs are broadcast Monday through Friday from 2am to $12 \mathrm{pm}$, and Saturday and Sunday from midnight to noon. WLUR's rotation consists of records the DJs are allowed to select from a pre-approved group selected by the music director. For the purposes of this study records sent to WLUR were simply "added" or "passed". At WLUR DJs are offered more freedom in selecting the rotation than at other stations. Whereas other station's rotations are tiered into Hots, Mediums, and Lights, WLUR simply selects albums which are approved for airplay. WLUR DJs are then afforded the freedom to select their own playlist from a list of pre-approved releases. WLUR also sends its' top 5 Adds to College Music Journal.

\section{Playlist Inclusion Data}

During the collection period, WLUR received a total of 59 unique releases from 20 unique promoters. Of the 59 total releases, WLUR included 32 of them in their airplay and rejected 27 of them for an inclusion rate of 54\%. The "Big 7" accounted for $35 \%$ of the 20 unique promoters WLUR had contact with during the data collection period. The "Big 7" sent 29 releases, accounting for $56 \%$ of the 59 total releases received at WLUR during the data collection period. The "Big 7" had 23 releases played and 6 releases rejected. The "Big 7" also accounted for $72 \%$ of the 32 accepted records at WLUR during the collection period as well as $30 \%$ of the 27 rejected records during the same period. The overall inclusion success rate for the "Big 7" during this period was 79\%. 
At WLUR, six of the "Big 7" had an inclusion success rate of 50\% and Planetary, Spectre, Team Clermont and Terrorbird all had 100\% of their releases included for airplay. AAM had 6 of their 7 releases included, and Pirate had 3 of their four releases included for airplay. Tinderbox was the least successful during this period, sending 6 releases but only having 2 included for airplay.

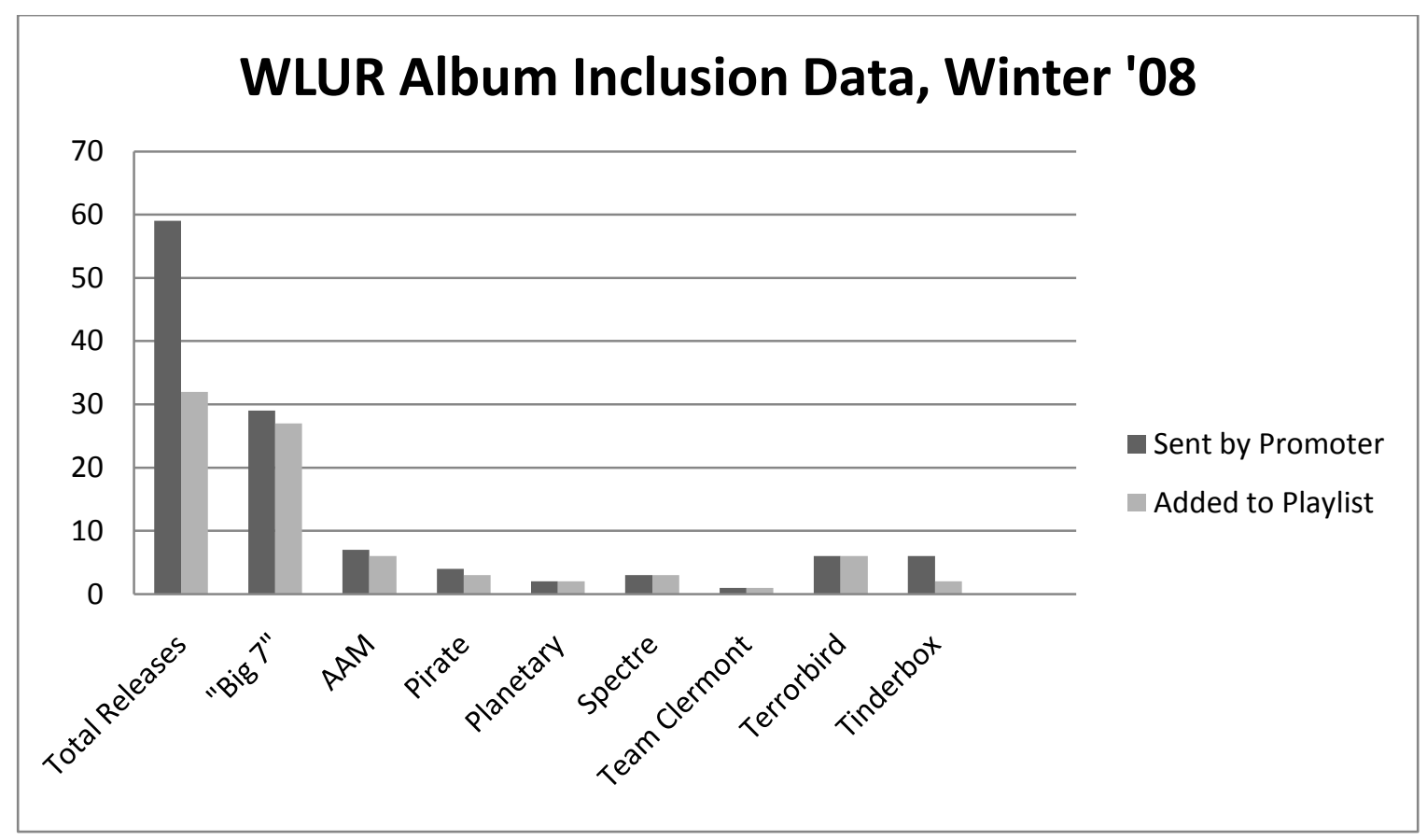

\section{WPTS, University of Pittsburgh, Pittsburgh PA}

WPTS is a 17-watt, non-commercial FM station owned and operated by the University of Pittsburgh. WPTS broadcasts at 92.1 on the FM from a transmitter located atop the Cathedral of Learning, with a broadcast radius of approximately 30 miles. WPTS broadcasts 24 hours a day throughout Pittsburgh and the surrounding region and their playlist is wide ranging, including specialty shows that appeal to all musical genres.

WPTS began broadcasting throughout Pittsburgh's FM market on August 26, 1984 after a long application process with the FCC. However, WPTS grew out of WPGH a carrier-current station set up to broadcast throughout the University of Pittsburgh's student union and 
dormitories. WPGH was founded in 1957 by a group of students led by Adrian Cronauer, whose experiences later in life as a military broadcaster were the inspiration for the film Good Morning Vietnam. WPGH was permanently converted to WPTS in 1977 when the University's FM station went on the air. WPGH are now the call letters for the local Pittsburgh television Fox affiliate.

WPTS devotes all of its daily schedule to music except for two sports reports totalling an hour and a half. Rotation at WPTS has three tiers, High, Medium and low. However, unlike the other two stations, there is a fourth option labeled "Drawer". The releases placed in the "Drawer" can be used for DJ picks, and can be reviewed for other station personnel so certain cuts can be played on air. For the purposes of this project releases labeled "Drawer" will be considered included in the playlist because DJs are given the option of playing them on-air. WPTS also reports their Top 5 Adds to College Music Journal each month.

\section{Playlist Inclusion Data}

During the collection period, WPTS received a total of 79 unique releases from 35 unique promotional companies. Of the 79 total releases, WPTS put 54 of them into rotation and rejected 25 of them for an inclusion rate of $68 \%$. The "Big 7" accounted for $20 \%$ of the 35 promoters WPTS had contact with during the data collection period. The "Big 7" sent 29 releases, accounting for $37 \%$ of the 79 releases received at WPTS. The "Big 7" had 17 releases played and 12 releases rejected. The "Big 7" accounted for 31\% of the accepted records at WPTS during the collection period as well as $48 \%$ of the rejected records during the same period. The overall inclusion rate for the "Big 7" for this period was $58 \%$. 
At WPTS six of the "Big 7" had a 50\% or better inclusion success rate, and five of the "Big 7" had a 100\% inclusion success rate. AAM and Terrorbird had all 3 of their releases included for airplay, Team Clermont had both of their releases included for airplay, while Pirate and Spectre each sent one release which was included. Planetary sent 4 releases and had two included for airplay. The least successful member of the "Big 7" again was Tinderbox.

Tinderbox sent 15 releases, by far the most that any one company sent, but only had 5 included for airplay, an inclusion success rate of $33 \%$.

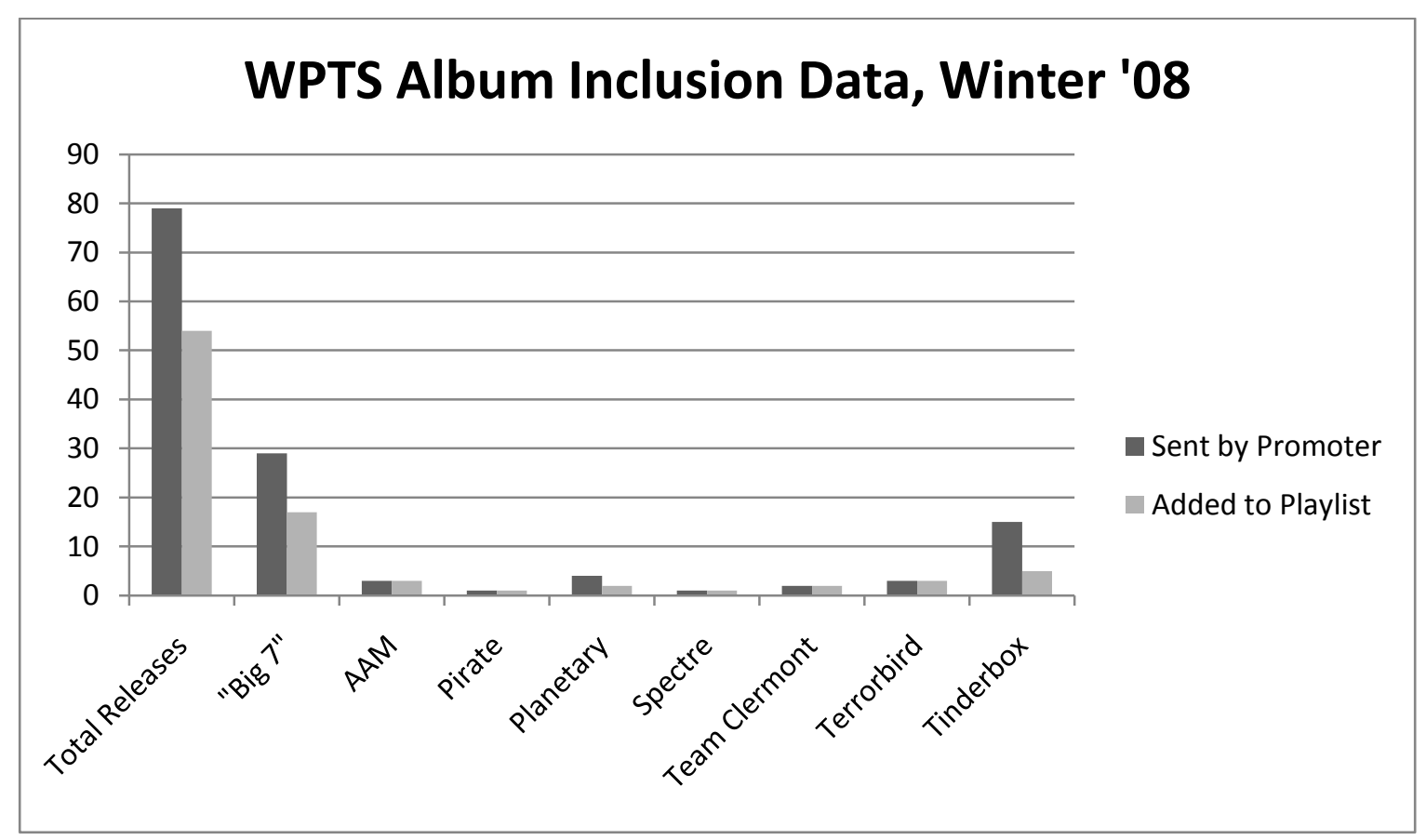

\section{WWVU-FM, West Virginia University, Morgantown WV}

\section{Playlist Inclusion Data}

During the collection period, WWVU received a total of 124 releases from 29 unique promotional companies. Of 124 total releases, WWVU gave 47 of them airtime, and rejected 77, for an inclusion rate of $38 \%$. The "Big 7" accounted for $24 \%$ of the 29 promoters WWVU had contact with during the data collection period. The "Big 7" sent 77 records, accounting for $62 \%$ of all releases received at WWVU. The "Big 7" had 29 releases played, and 48 releases rejected. 
The "Big 7" accounted for $62 \%$ of the accepted records at WWVU during the collection period as well as $62 \%$ of the rejected records during the same period. The overall inclusion rate for the "Big 7" for this period was 38\%.

At WWVU only two of the "Big 7" had a $50 \%$ or better inclusion rate. Pirate sent 9 releases and had 5 included in the playlist for a $55 \%$ inclusion rate. Terrorbird sent 12 releases and had 6 included in the playlist for a 50\% success rate. One other member of the "Big 7" had an inclusion rate higher than the Big 7's overall success rate of 38\%. AAM, which sent the most releases, 25 total, had 12 included for airplay for an inclusion rate of $48 \%$. Spectre sent 3 releases, 1 included for airplay, for an inclusion rate of 33\%. Team Clermont sent 8 releases, 3 included for airplay, for an inclusion rate of 38\%. Planetary sent 19 releases, 3 included for airplay, for an inclusion rate of $16 \%$. Tinderbox sent 4 releases, and once again had none included for airplay.

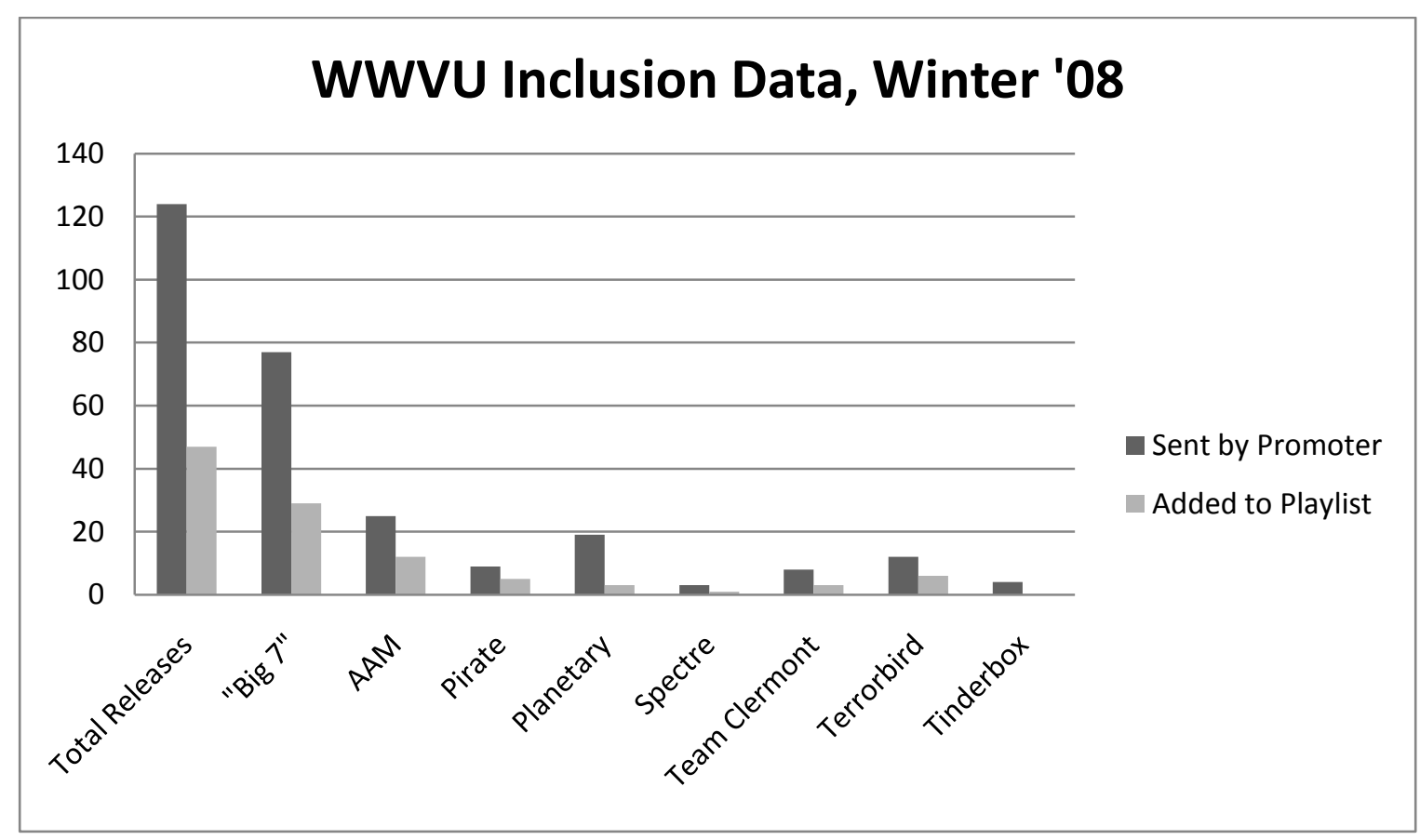




\section{Chapter 4: Music Director Interviews and Discussion}

Examining the data collected only tells half the story of the importance of the record promoter and music director interaction. To support the evidence and conclusions presented in the last chapter, interviews were conducted with music directors at all three stations participating in this study. WLUR music director Michael Morella, WPTS music director Emily Tantillo, and WWVU music director Rupam Sofsky, assistant music director Daniel Conway and metal director Jesse Novak were interviewed for this thesis. Their responses have been aggregated and are presented anonymously to protect their working relationships.

All music directors were in agreement about the same two key factors in including music on their station's playlist that the original study found. The first was music that "fit" their station identity. Though never explicitly stated in terms of sounds and genres all directors interviewed had a very defined view of what music should be included on the playlist for their independent station. The factor was the working relationship between the music director and the record promoter.

Each interview again started by asking the music directors [MDs] to describe the music selection process at their station. Though each station had slight variations to their rotation system, the process by which each station received music was the same. Each music director served as his or her station's contact for a wide range of record labels and promotional companies. Each week the music director received new music for his or her review. MDs also held office hours during which they had contact with promoters who had sent them records. It was always the music director's decision about which records were included or excluded from airplay. Each music director took this gatekeeping role very seriously. 
But what music fits, and what does not fit? Each station touted a diverse playlist that crossed many genres. While most commercial radio is tightly programmed to highlight a certain kind of music, college radio eschews that capitalizing on "independent". Each music director claimed to have a very clear understanding of what worked for his or her station. This can be traced back to their opinion on what the ethos of college radio actually stands for. "To me college radio is going against the grain of what everyone else in the industry is doing," responded one music director. Another felt college radio was, "no commercials, music that's noisier, music that's hopefully against the grain in many respects, specialty shows, and things you're not going to hear anywhere else on any kind of commercial radio stations."

One music director felt that it meant, "giving artists that don't really have a shot at getting on mainstream radio, airplay. Our format is progressive, which we perceive as artists you can't hear anywhere else... up and coming things, brand new stuff. And underground things." Another described his station as, "fighting the good fight and providing a service you're not going to get anywhere else."

The music directors understood the commercial role that many radio stations play within the record industry. Without that promotion, many artists wouldn't be a financially successful investment for their record company. Though they fully understood that, they felt that the support artists receive from college radio was much more honest. "We do it because we care about the music we're playing and we don't want to play music that can either be in the background or that you can hear anywhere else. We want to have a unique identity and play unique bands".

All the music directors felt a sense of pride in the independence of their jobs. "I think that what sets it apart is the fact that [DJs] don't have to answer to anyone," one said. "They 
don't have to worry about if people are listening, they don't have to worry about Arbitron ratings or anything like that. They can really play whatever they want. Your real sense of responsibility should be to the listener and to the DJs. It's sort of by the people, for the people, in a sense."

"I think just the personality of it is different from mainstream radio," responded another music director. "I think it's more like the community's more involved with it because they can come up and do whatever they want with it. I think the personality is more open."

One of the music directors also noted that freedom to do what you enjoy opened the playlist up to new and interesting things that you can't do or find on commercial radio.

Just as the music directors had a very defined view of what college radio should be, they also shared very opinionated ideas of what should be played on their station. Sometimes this had to do with the style of music, and the music director's desire to keep the station's sound varied and not slanted towards one kind of music or another. "There's certain styles of music as well that don't fit our format," responded one. "We do play the quiet folk music, but there's so much of that stuff, folk, quiet singer songwriter type things that we get so many every week that we can only play the best". He also said that his decisions weren't made principally based on genre, but what he perceived to be the best of that genre, which could be blended with other music to form his station's cohesive "sound."

Keeping their station sounding diverse was a re-occurring theme for many of the music directors. One music director clearly laid out his plan to have all genres of music represented throughout all tiers of his station's rotation and included everything from quiet singer songwriters, to loud noise rock, to dance oriented electronica. To him, it was about the quality of the music, not the specific genre the music fits within. He also looked for things that didn't fit 
into any specific genre. "If there's anything that doesn't fit those criteria... then we're going to try and get that stuff in there too, if we can have it," he said.

A band's position within the record industry also seemed to play a key role in whether their music was included, as well as the sound of the band itself. One of the music directors said that their main criteria before even reviewing a CD was if they knew the artist or not. "If we know the artist and they're being played on other radio stations, then we don't even bother reviewing it," they remarked.

The music directors very clearly felt that their gatekeeping role at their stations should be used to support artists they felt needed the support. One music director pointed out that sometimes they would get an album that didn't need their help since it was already being heavily promoted through traditional means such as music videos and television commercials. The example cited was pop songstress Katy Perry, whose sound fits with much of what his station plays, but her position within the record industry did not. This represents a shared notion among all music directors that they are in a position to support artists they feel are deserving. The flipside, of course, is that there are artists which they feel are not deserving. Many times they will reject an artist because they do not like the music, but other times they feel like the artists simply do not need the support, so they should not give it.

Each also felt they were the primary person involved in making their station what it was. One of the music directors called their job "a privilege". He was conscious that he had to "do right" by the station, the DJs and the listeners. "It's a kind of influential position in that sense," he said. Another believed that their job was important because they made sure the station's music was progressive and current. 
"If there wasn't a music director, no one would send us CDs and nothing would get reviewed and our content at the station here would just get really stale and old," they noted.

Though each director had many thoughts on their role as liaison to the record promoters, they all felt they also served as the voice of their station's DJs. One music director felt that one of the most important facets of their job was 'knowing that each person who DJ'd here represented people in the listening audience. Even if it's their friends, or people who they share their tastes with, they're probably listening to their show and want to hear that same stuff, so you've got to have that in there." They felt that they knew that "if they're here working, then there's probably other people out there that want to hear that same stuff."

Another Music Director said, despite personal tastes, they needed to be constantly aware of the tastes of others at their station. He felt that he personally enjoyed almost all of what was played on his station.

Another music director stressed giving DJ's tastes a chance. "I think the station would be a lot worse if I was the only one reviewing everything," they replied. "Because then high rotation would only be girly upbeat indie-pop because that's what I listen to. I think it's really good that everybody can review things so they can give a different viewpoint or idea of how good something is."

Ultimately though, the music director is the person who connects the DJs with the music they play, and the promoter who provides the music to the station. 'Most of the time when I'm talking to one, I'll mention the other," said one music director. "If I'm talking to a DJ, I'll say you like this band, well this promoter sent us this album and you'd probably like this. And then to the promoter I may end up saying 'our DJs aren't liking that thing that you sent us'.” 
Whether they were serving as a liaison between promoter and DJ, or as the gatekeeper of the stations playlist, all music directors felt the promoter-music director relationship was a key part of their job. "I think that there's a give and take to it. They have to be able to accept that occasionally you're not going to be able to play certain records of theirs, or maybe you're not going to add certain records of theirs," one music director said. "I do think that it's up to the music director to not just say, when they ask you about a record during your weekly hours, and you say 'we're not going to play that' and they ask why, they deserve a better answer than, oh I'm just not into it". They feel that something should come out of his assessment of all of the records, regardless of whether they were added or not.

The music directors also agreed that their relationships varied from promoter to promoter, some being more personal, some more professional.

One music director stressed the tight connection between their station and the promotional company Advanced Alternative Media. "It's different from promoter to promoter, he said. "I got the DJ who trained me an internship at AAM, who we've always had a good relationship with, and now he calls me every week. I will literally do whatever those guys want, and I don't feel bad about saying so." However, the differences in relationships weren't always positive. "Other promoters, they may be sending us good music or decent music, or they don't call me," noted the music director. They also said that the relationship would shift over time as new people came on board. "There's a lot of elements, just like any relationship, sometimes somebody dicks you over somehow or you accidentally inadvertently dick over someone else and they hold it against you for awhile," they added.

Since the end goal of the record promoter is to make sure that the artists they represent get their music on the air, often times promoters will try and insist that something get played. 
It's something music directors felt pressure to acquiesce to at times, but to stand up at others. "They can say whatever they want at me and I can say 'oh yeah, sure' and write down that they said this was good," replied a music director. "But it's still going come down to me listening to it and making that decision. I don't know how other stations are, and I don't know how other music directors are, it's a personal thing. I take what they're telling me, and it's in the back of my mind or I wrote it down, but at the end of the day, I could care less what they want."

Each music director agreed that promoters were an important part of their job, though their opinions how much influence the promoters had was varied. Some felt their influence was very prevalent. "They actually have a huge influence because the major promotion companies, like AAM, send the best music," one remarked. They also admitted that they were more excited to receive packages from AAM, and that their relationship with the promoter at Pirate was much of the reason their submissions were reviewed first. Of those promoters who didn't maintain a personal relationship, they said, "I don't feel any obligation to review their stuff. If the CD comes in and I've never heard of it, and the album art doesn't look interesting then I'll just throw it in the drawer and I won't bother with it."

One felt that the influence varied from promoter to promoter. They explained that each relationship was different in how it would impact the process. "How much they're dealing with me, what our past relationships have been like. It's also interesting because the promoters themselves, sometimes have their own motivations," they said.

Some took a very hard-line in being the sole selector of their station's music. One music director felt that it was just about the music. "With all the promoters and all that stuff, it's part of the business, there's probably a lot of stations that are probably just playing exactly what they told them, to play in their rotation because some music directors probably don't care or put in the 
effort," he remarked. He also felt that he had to hold WWVU to a different standard. "As far as our station goes, that's our top priority, making it a personal thing. We're not ever going to just play what someone tells the station to play."

One music director was clear that he saw to it that some promoters would get better treatment than others. "There were people who work at some of those promotion companies that I was very fond of," he said. "I think, likewise, I think some of them were very fond of me, I think we had great relationships. Where I wanted to help them out if I could, I wanted to play something that they sent even though I wasn't very into it." He felt that by giving certain promoters preferential treatment he was simply helping to make "someone's job a little easier" but not compromising his station's integrity. "Sometimes, at work, you have to do things you don't want to do, it's just the way things are," he said.

Another said that he didn't see any harm in letting the promoter have a little influence from time to time. "You can try to have some idealist douche bag hipster fucking mentality about it, but I don't think that's necessarily any better than bending a little bit," he said. "I was firm enough when I needed to be, saying 'it's not going to get played here'. But there has to be some elasticity to how you deal with things, you can't just say 'no we're not going to do it!' that's not forging a relationship."

However, the music directors understood that the promoters play an important role in shaping the sound of their station, simply by providing information and making music accessible. "They could send us the stuff, with the information, and we could just make the decision ourselves," said one. "But it's sort of like, it's all up to us, when they call it's sort of like that guidance. They'll say things like 'these are the things we're really excited about'. They'll just straight up tell you that half of the stuff that they sent you was what they really wanted you 
to play, they'll tell you what other stations are getting pushed to play. It kind of gives you that idea of what the important things are for them."

The music directors also understood that to have contacts within the traditional record industry made it easier for their stations to access things they would not be able to otherwise. "It helps for other things such as getting things that we giveaway on air, like tickets to shows, and the freebie promo stuff," another replied. "That's one thing that we can actually tell them what our listeners would want to giveaway, what concerts are in the area. You set up things like bands coming in and doing stuff on air, like playing or an interview while they're on tour. It's those types of things, those extra things that come along, we're playing their stuff or whatever and they'll do things for our station as well'. They did not feel that this was tantamount to bribery. “It's not like, owed, or it's not like we're doing things just so they'll help us out," she said. "We're doing little things for lots of people and that pretty much does it. It's just a mutual appreciation for each other."

Another said that, "it's weird, because the bands are the ones making the music. And then the bands give it to the labels, and the labels are the ones who have to talk to promotion companies. They're super vital." He also felt that the promoters could influence the music industry as much as radioplay. He felt that the give and take between the promoters and the music directors was obvious when the music directors were asked who needed whom more. "We need them to keep us getting good stuff and kind of make it a little easier for us to have access to all this stuff we wouldn't necessarily get otherwise," one responded. "But also, they need us. They're getting paid to get us to play their stuff, they're getting paid to work this stuff on radio so without us they wouldn't have jobs. Without them we wouldn't have all the good music that just arrives at our door. You couldn't have one without the other." 
One of the music director felt that they wielded more power. "They definitely need us more," he said. "Promoters would be out of a job if there was no college radio or if we didn't listen to them. Their success with promoting an album is based on how many spins they get on college radio, and if the music directors listen to them." However, he also added that, "the way the system is, we're not going to get much music if we alienate a promoter completely, so they're certainly important."

Despite the music directors' willingness to acknowledge shared power with the record promoters, none knew exactly how they were viewed by their counterparts in the record industry. One music director said that, "Sometimes I feel like they probably get frustrated with music directors I'm sure because a lot of times a lot of stations, you just have college kids, you don't have the longevity, you don't have anyone who can get really good at what they're doing."

Another felt that "I think they probably view me as someone they're just working with more so than a friend but, they are very friendly people. They're nice to me because they need me. They need me to do things for them, to keep them to keep a job to make sure they're successful in their job. I think it's more of a business relationship, but I think that if I were to go to their shows and their parties, then I think it could be like a friendship, but I haven't done any of that yet, so I don't know. As It stands know I think it's more like a business thing.

"Just a tool to get a job done," a music director responded bluntly. "In terms of the average music director, just a means to an end. I think there's probably people who stand out for them, who are particularly bright, or good at what they do, have good taste, which is ridiculous. But within that sphere you're going to have to deal with things like that. For the most part, you're being used as a tool to get that album to number one, which should always be the goal for everything." 
"It's sort of like you're all in the same boat, but they're just a step above us," one said while acknowledging that music directors and record promoters often share the same heritage. “Most of them were MDs at some point, and they're working with college radio they probably came from college radio. They were probably a MD and probably sympathize with them, but I'm sure it's frustrating."

While they all acknowledged their importance, the music directors were split over whether or not they could do their job without record promoters. One music director felt that he could find the music on his own, because of recent technological innovations in downloading music online. He understood, however, that in order for him to get all the music he needed, he would have to resort to illegal filesharing. However, he felt that to keep his music search legal, he would still have to have a relationship with all of the record labels that sent him releases, and that would actually increase the number of people he had to speak to. "You technically do need them, as far as finding music, we wouldn't be as good. Because they're sending stuff and I'm thinking, oh yeah, I heard about this, I've been wondering, I'd just heard something about it and it was supposed to be good."

"I don't think I could," another stated flatly about doing her job without promoters. “There are so many record labels out there I don't think we'd get as many CDs in our station if there weren't promoters. Because the promoters, they send us CDs from a bunch of different labels, and they put little reviews on them, little stickers and that helps out a lot. Picks from each $\mathrm{CD}$, it makes reviewing them a lot faster and it gives us all these CDs with a lot less effort."

Another felt he could do his job without the promoters, but that just created a variety of new problems. "We could do it, it would make us really biased, but we could do it. The problem that would arise, however, is that without promoters people only go after what they already know 
about. When you turn on the radio, especially a college radio station, you can hear absolutely anything from anywhere," he said.

The MDs also cited recent music technological advances as a reason college radio is even more vital. "To listen on iPods and the Internet and strictly on a computer, and not on a radio station, the advantage is you have control. The advantage is that whatever your mood is you scroll down or up, and you pick what you want to listen to. But the extreme, extreme, disadvantage is that you're only going to want to play and listen to things that you'd already known about beforehand." 


\section{Chapter 4 Conclusion / Limitations of this Study}

As you have seen, major record promotion companies who have constant contact with music directors, while flooding their stations with music, have much greater success getting their music added to playlists than smaller independent artists or record labels. This is clearly obvious in all of the data collected at all three stations. The date representing the records received at their stations, and records added to the playlist at their station, shows that the overwhelming majority of it comes from the "Big 7" record promoters. These promoters flood college radio stations with material, and constantly contact music directors to pressure them to add their music to the playlist.

This contact with music directors is the defining characteristic of whether or not music gets added to the playlist. Though all music directors interviewed stated that they had the final say in what music gets accepted and rejected, all suggested their relationships with record promoters was a key part of their job. Most felt that if they didn't add enough of that company's records, then it was possible that their station would stop receiving music. Though keeping working relationships going through compromise is a major part of any real-world industry, it seems to be counter to college radio's musical identity that is rooted in independence and alternativeness.

Both aspects of this study, both in data collected from stations and from interviews with those stations music directors, showed that the influence that the mainstream record promotion industry had on college radio playlist programming was substantial.

This study was limited by three key factors. First, was the time during which record inclusion data was collected. As seen by the large drop-off in total records received by WWVU 
from the initial study (March/April) to the second study (November/December), it can be surmised that a more ideal time of year would be in either the Fall or Spring. Also, the thirty-day data collection period could be expanded to a full semester. The fact that only two unique releases were received by all three stations, yet twenty seven unique releases were received by two of three stations indicates that the time when records are received by stations (noted as the day a Music Director opens the promotional package, not when it was mailed) may vary greatly. In future studies it would help to expand the collection process to an entire semester to collect data so as to get a larger sample to compare between stations.

Secondly, the scope of the study could be increased by including more radio stations. This study originally began with ten stations within the region identified as possible participants. Four stations responded that they would participate, but only three stations completed the data collection process. Three stations is an adequate sample for this project, however a more comprehensive study could include as many stations as possible. Ideally, future studies would include ten stations or more of similar size, spread equally throughout the country.

It also would be beneficial to include the reactions and opinions of some record promoters within the scope of this study. They were excluded principally because it was their influence that was being measured. To ask them if they were attempting to influence the decisions of music directors would be like asking a train conductor if he was trying to drive a train: it's a given. Any record promoter who would be asked would answer in the affirmative. However, some insight into their thought process and the manner in which they attempt to subtly influence music directors would be beneficial to future studies. 
Finally, it would benefit future studies to develop a more systematic approach to data collection. Simple surveys left to Music Directors to fill out leave room for error. If there were a way to collect logs from record promoters indicating which stations were sent which records, and then correlate those logs with station playlists, the collection of data would improve greatly. 


\section{Future Research Implications}

This study shows that record promoters wield a great deal of influence over college radio music directors. Further research should be conducted to ascertain if that influence compromises the integrity of college radio playlist programming. While the act of programming college radio is still done by individuals and by hand, an entire industry exists with the sole purpose of influencing that decision making process. Because this is the first contact many college music directors have with the music industry at large they are often swayed into supporting those industry professionals who they feel they connect best with. The next evolutionary step for this research project would be to approach this relationship from the promoter side and see which clients (labels/acts) they have the most across the board success with, and why. 


\section{Appendix 1: WWVU, Records Received/Inclusion Data, 11/15-12/15/08}

\begin{tabular}{|c|c|c|c|c|}
\hline $\begin{array}{l}\text { Date } \\
\text { Rec'd. }\end{array}$ & Artist & Album & Promoter & Location \\
\hline \multirow[t]{42}{*}{ 15-Nov } & Ryan Auffenbergs & Marigolds & Planetary & \\
\hline & The Bad Handd & In this Line & Terrorbird & \\
\hline & Bloc Party & Intimacy & Syndicate & Add-Hot \\
\hline & Black Swan Green & The Ruin Gaze & None & Medium \\
\hline & Corrin Campbell & Exhibti A & Tinderbox & \\
\hline & Chop Chop & Screens & Team Clermont & Light \\
\hline & Keith Cornella\&Broken City & Arms Are Falling & Powderfinger & \\
\hline & Dark Dark Dark & The Snow Magic & Terrobird & \\
\hline & Jesse Dee & Bittersweet Batch & Planetary & Hot \\
\hline & Desolation Wilderness & White Light Strobing & Team Clermont & Medium \\
\hline & Bob Dylan & Tell Tale Signs & Syndicate & \\
\hline & The End of the World & French Exit & Pirate & Medium \\
\hline & Final Fantasy & Spectrum 14th Century EP & AAM & Light \\
\hline & Frontier Ruckus & The Orion Songbook & Terrorbird & \\
\hline & Future Clouds \& Radar & Peoria & Fanatic & Light \\
\hline & Tom Gabel & Heart Burns EP & None & Light \\
\hline & Gay Blades & Ghosts & Planetary & \\
\hline & Giraffe Running & $\mathrm{S} / \mathrm{T}$ & Apples \& Cats & \\
\hline & Grampall Jukebox & Hopechain & Terrorbird & \\
\hline & Hey Monday & Hold on Tight & Planetary & \\
\hline & The Hush Now & $\mathrm{S} / \mathrm{T}$ & Spectre / Pirate & \\
\hline & Int'I Noise Conspiracy & The Cross... & Pirate & Medium \\
\hline & Live & Forever Single & Vanguard & \\
\hline & Longwave & Secrets Are Sinister & Planetary & Medium \\
\hline & Love Is All & A Hundred... & AAM & Add-Hot \\
\hline & Mascott & Art Project & AAM & \\
\hline & ohGr & Devils & Apples \& Cats & \\
\hline & Past Lives & Strange Symmetry EP & Spectre & Light \\
\hline & Peachcake & What Year & Pirate & \\
\hline & Pee Pee & Castile Jackine & Massive Music & \\
\hline & Pegataur & Eternal Flight & Terrorbird & Add-Hot \\
\hline & Kito Peters & Too Much Light & Planetary & \\
\hline & Jay Reatard & Matador Singles '08 & $\mathrm{XL}$ & Hot \\
\hline & Red Datsun & $\mathrm{S} / \mathrm{T}$ & Mia Mind & \\
\hline & The Rollo Treadway & $\mathrm{S} / \mathrm{T}$ & Team Clermont & \\
\hline & Calvin Scott & Barack Obama & Roaring Lion & \\
\hline & The Secret History & Desolation Town EP & Fanatic & \\
\hline & Kyle Siegel & Casting Memories & Tinderbox & \\
\hline & The Takeover UK & It's All Happening & Planetary & Light \\
\hline & Viva & Electric Caberet & Planetary & \\
\hline & Von Iva & Girls On Film EP & Planetary & \\
\hline & Yelle & Ce Jeu EP & Astralwerks & Light \\
\hline \multirow[t]{3}{*}{ 17-Nov } & A Block of Yellow & Do I Do & Terrorbird & \\
\hline & American Astronaut & Reno EP & Lift & \\
\hline & Bionic & Black Blood & AAM & \\
\hline
\end{tabular}




\begin{tabular}{|c|c|c|c|c|}
\hline & Blackmarket & Elephant in the Room & Planetary & \\
\hline & The Buttless Chaps & Cartography & None & Light \\
\hline & Julliette Commagere & Queens Die Proudly & Pirate & \\
\hline & Dead Leaf Echo & Pale Fire & AAM & Light \\
\hline & Dillinger Four & Civil War & Pirate & Medium \\
\hline & The Escape Frame & $\mathrm{S} / \mathrm{T}$ & Planetary & \\
\hline & Fiftywatthead & Fogcutter & AAM & Medium \\
\hline & French Miami & $\mathrm{S} / \mathrm{T}$ & Terrorbird & Medium \\
\hline & Gringo Starr & All Y'all & Team Clermont & \\
\hline & The Handcuffs & Electroluv & Organic & \\
\hline & Her Space Holiday & XOXO... & None & Add-Hot \\
\hline & Frida Hyvonen & Silence is Wild & Chouette & Light \\
\hline & Keane & Perfect Symmetry & AAM & Medium \\
\hline & The Knux & Remind Me... & AAM & Medium \\
\hline & The Layaways & The Space Between & AAM & \\
\hline & Lionize & Space Pope & Planetary & \\
\hline & Manchester Orchastra & Let My Pride... & None & Light \\
\hline & MC Frontalot & Final Boss & Pirate & Medium \\
\hline & Medeski Martin \& Wood & Radiolarians I & Spectre & \\
\hline & Megapuss & Surfing & Vapor & Add-Hot \\
\hline & Mike \& the Ravens & Noisy Boys & None & \\
\hline & Origami Ghosts & Short Momentum & Planetary & \\
\hline & The Points & $\mathrm{S} / \mathrm{T}$ & AAM & \\
\hline & Push-Pull & Hello Soldier! & AAM & \\
\hline & Lou Reed & Berlin:Live & Beggars Group & Medium \\
\hline & The Rockwells & Place \& Time & Team Clermont & \\
\hline & Anni Rossi & Afton & Beggars Group & \\
\hline & Secret Dakota Ring & Cantarell & Planetary & \\
\hline & Edie Sedgewick & Things & AAM & \\
\hline & Ty Segall & $\mathrm{S} / \mathrm{T}$ & AAM & Hot \\
\hline & Starkeys & Dilmun EP & Tigers Against Crime & \\
\hline & State Shirt & This Is Old & Fanatic & \\
\hline & That Ghost & Young Fridays & AAM & Medium \\
\hline & Three Second Kiss & Long Distance & AAM & \\
\hline & True Widow & $\mathrm{S} / \mathrm{T}$ & Planetary & \\
\hline & Titles & Up With the Sun & AAM & \\
\hline & Trash Talk & $\mathrm{S} / \mathrm{T}$ & AAM & \\
\hline & The Visitations & The Conundrum Tree & None & \\
\hline & Waking Lights & Songs for Jo & Fanatic & \\
\hline & Wallpaper & $\begin{array}{l}\text { On the Chewing Gum } \\
\text { Ground }\end{array}$ & Team Clermont & Medium \\
\hline & J.Roddy Walston & Hail Mega Boys & AAM & \\
\hline & The Weather Machines & Bones and Brains & Tigers Against Crime & \\
\hline & Whales and Cops & Great Bouncing Icebergs & AAM & Light \\
\hline & Elizabeth Willis & $\mathrm{S} / \mathrm{T}$ & Fanatic & \\
\hline & Rachel Yamagata & Elephants... & Warner & Light \\
\hline & The Younger Sister Band & The Lady.... & AAM & \\
\hline \multirow[t]{2}{*}{ 30-Nov. } & Anathallo & Canopy Glow & Terrorbird & Add-Hot \\
\hline & Dead to $\mathrm{Me}$ & Little Brother & Pirate & \\
\hline
\end{tabular}




\begin{tabular}{|c|c|c|c|c|}
\hline & The Deep Vibration & Veracruz & Syndicate & \\
\hline & Don't Wanna Die & My Federation & Planetary & \\
\hline & The Electric Grandmother & The Stenographics & All Hail Records & \\
\hline & Fall Electric & Measure and Step & AAM & Medium \\
\hline & Flo & $\mathrm{S} / \mathrm{T}$ & Tinderbox & \\
\hline & David Grubbs & An Optimist... & AAM & Light \\
\hline & Todd Hannigan & Volume $2 \ldots$ & Planetary & \\
\hline & Heroes of the Dancefloor & Torch & Planetary & \\
\hline & Ulaan Kohl & II & Chouette & \\
\hline & Killola & I Am the Messer & Fanatic & \\
\hline & The King Left & New York Nothing & Syndicate & Light \\
\hline & Hilde Marie Kjerson & A Killer... & Chouette & \\
\hline & Julian Koster & The Singing Saw & Merge Records & Light \\
\hline & Lights On & $\begin{array}{l}\text { Waiting for the Heart to } \\
\text { Beat }\end{array}$ & Team Clermont & \\
\hline & The Loom & At Last Night & Fanatic & \\
\hline & Lorna & Writing.... & AAM & \\
\hline & Loumo & Convivial & Chouette & \\
\hline & Don Peluso Band & EP & Tinderbox & \\
\hline & The Rapture & Tapes & Spectre & \\
\hline & Religious Knives & The Door & Terrorbird & \\
\hline & Roll the Tanks & Police Me Single & Pirate & \\
\hline & Sea Sick & $\mathrm{S} / \mathrm{T}$ & AAM & Medium \\
\hline & Skeletons & Money & Terrorbird & Add-Hot \\
\hline & DM Stith & Curtain Speech & Team Clermont & \\
\hline & White Light & Black Acts & AAM & \\
\hline & Wintersleep & Welcome & Pirate & Medium \\
\hline & Various & Bruce Perry Presents & Kensaltown & Light \\
\hline & Various & Sounds Australia Vol 2 & Planetary & \\
\hline \multirow[t]{3}{*}{ 8-Dec } & Hush Arbors & $\mathrm{S} / \mathrm{T}$ & Terrorbird & Light \\
\hline & Ladyhawke & $\mathrm{S} / \mathrm{T}$ & Terrorbird & Add-Hot \\
\hline & Common & Universal Mind Control & Geffen & Add-Hot \\
\hline
\end{tabular}


Appendix 2: WPTS, Records Received/Inclusion Data, 11/15-12/15/08

\begin{tabular}{|c|c|c|c|c|}
\hline $\begin{array}{l}\text { Date } \\
\text { Rec'd. }\end{array}$ & Artist & Album & Promoter & Location \\
\hline 17-Nov & Arliss Parker & Handsome Like a Lion & Clermont & Add-High \\
\hline 17-Nov & Supersuckers & Get It Together! & Planetary & \\
\hline 17-Nov & $\begin{array}{l}\text { Todd Hannigan \& the } \\
\text { Heavy 29's }\end{array}$ & $\begin{array}{l}\text { Vol. 2: Courtside for the } \\
\text { Apocalypse }\end{array}$ & Planetary & drawer \\
\hline 17-Nov & Matt Duke & Kingdom Underground & Planetary & Med \\
\hline 19-Nov & Totally Michael & Totally Michael & AAM & drawer \\
\hline 19-Nov & Hearts Revolution & Switchblade EP & AAM & drawer \\
\hline 19-Nov & Decemberists & Always the Bridesmaid & Capitol & Add-High \\
\hline 19-Nov & Listing Ship & $\begin{array}{l}\text { A Heart Full of Oil and } \\
\text { Bone }\end{array}$ & Clermont & drawer \\
\hline 19-Nov & Belle and Sebastian & The BCC Sessions & Matador/Beggars & Add-High \\
\hline 19-Nov & Rosie Thomas & A Very Rosie Christmas & Nettwerk & Add-Low \\
\hline 19-Nov & $\begin{array}{l}\text { Chesty Malone \& the Slice } \\
\text { 'Em Ups }\end{array}$ & $\begin{array}{l}\text { Now We're Gonna See } \\
\text { What Disaster Really } \\
\text { Means }\end{array}$ & none & \\
\hline 19-Nov & Bodies Obtained & From the Top of My Tree & Syndicate & drawer \\
\hline 19-Nov & Stereophonics & Decade in the Sun & Syndicate & Low \\
\hline 19-Nov & Pretend You're Happy & Pretend You're Happy & Terrorbird & Med \\
\hline 19-Nov & $\begin{array}{l}\text { Tippy Canoe \& the } \\
\text { Paddlemen }\end{array}$ & Parasols and Pekingese & The Bloomers Works & drawer \\
\hline 19-Nov & Leah & I'm Not Goin' Nowhere & Tinderbox & Low \\
\hline 19-Nov & River Raid & The River Raid & Tinderbox & drawer \\
\hline 19-Nov & Rivers Cuomo & Alone II & Universal & Med \\
\hline 19-Nov & Various Artists & Verve Remixed Christmas & Verve & drawer \\
\hline 21-Nov & Anjulie & Boo & Concord & \\
\hline 21-Nov & Let Go & Tomorrow Handles That & Tinderbox & drawer \\
\hline 24-Nov & Drew Danburry & $\begin{array}{l}\text { This Could Mean Trouble, } \\
\text { You Don't Speak for the } \\
\text { Club }\end{array}$ & Apples and Cats & High \\
\hline 24-Nov & Gentleman Auction House & Christmas in Love & $\begin{array}{l}\text { Apples and } \\
\text { Cats/Vitriol }\end{array}$ & $\begin{array}{l}\text { Holiday } \\
\text { Rotation }\end{array}$ \\
\hline 24-Nov & Death Cab for Cutie & Something About Airplanes & Barsuk & Med \\
\hline 24-Nov & Tina Vero & Tina Vero & Indigo Planet & \\
\hline 24-Nov & Frederick Isaac & Christmas Fantasies & Planetary & \\
\hline 24-Nov & Various Artists & $\begin{array}{l}\text { Best of Woodsongs, } \\
\text { Volume Three }\end{array}$ & Poetman & drawer \\
\hline 24-Nov & Various Artists & $\begin{array}{l}\text { Acoustic Rainbow: Roots } \\
\text { Volume } 33\end{array}$ & Poetman & Add-Low \\
\hline 24-Nov & Reinharts & $\begin{array}{l}\text { Hard Bop Born of Sweet } \\
\text { Hell }\end{array}$ & none & drawer \\
\hline 24-Nov & Caleb Travers & Blue Weathered Dreams & Tinderbox & \\
\hline 24-Nov & Chris Braid & Chris Braid & Tinderbox & \\
\hline 24-Nov & Spit Hot Fire & Spit Hot Fire & Tinderbox & \\
\hline 24-Nov & Shiny Toy Guns & Ghost Town & Universal & \\
\hline 24-Nov & Fleshtones & Stocking Suffer & Yep Roc & drawer \\
\hline 26-Nov & Various Artists & Live from Radio $\mathrm{K}$ & AAM & drawer \\
\hline
\end{tabular}




\begin{tabular}{|c|c|c|c|c|}
\hline 26-Nov & Take No Damage & Shambles & All Hail Records & drawer \\
\hline 26-Nov & PEAS & A Christmas Chill & Apples and Cats & drawer \\
\hline 26-Nov & Moon \& Moon & VII Acts of an Iron King & Apples and Cats & drawer \\
\hline 26-Nov & Tommy James & I Love Christmas & Aura & \\
\hline 26-Nov & Gonken & Robot vs Zombie & Automation & drawer \\
\hline 26-Nov & Abiku & Left & Automation & drawer \\
\hline 26-Nov & Kanye West & 808s and Heartbreak & Island/Def Jam & \\
\hline 26-Nov & American Astronaut & Reno & Lift & drawer \\
\hline 26-Nov & Dirty Heads & Any Port in a Storm & Lift & Low \\
\hline 26-Nov & Arden Kaywin & The Elephant in the Room & PEGA & \\
\hline 26-Nov & Los Campesinos! & $\begin{array}{l}\text { We Are Beautiful, We Are } \\
\text { Doomed }\end{array}$ & Pirate & drawer \\
\hline 26-Nov & Various Artists & $\begin{array}{l}\text { The Platform One } \\
\text { Underground Rush } 004\end{array}$ & Platform One & \\
\hline 26-Nov & Franz Ferdinand & Ulysses & Sony & \\
\hline 26-Nov & $\begin{array}{l}\text { Margot \& the Nuclear So } \\
\text { and So's }\end{array}$ & Daytrotter Sessions & Sony & drawer \\
\hline 26-Nov & Steve Northeast & Inside & Tinderbox & \\
\hline 26-Nov & Minneapolis Henrys & The Way of the Albatross & Tinderbox & drawer \\
\hline 1-Dec & Novel & $\mathrm{IAm}$ & EMI & Add-Med \\
\hline 1-Dec & Killers & Day \& Age & Island/Def Jam & \\
\hline 1-Dec & Union Line & The Union Line & none & High \\
\hline 3-Dec & Pudding Attack & Miniskirt Cash Machine & Acidsoxx & drawer \\
\hline 3-Dec & Mondocane & Music Inspired by & Acidsoxx & drawer \\
\hline 3-Dec & Little Bang Theory & Elementary & Acidsoxx & drawer \\
\hline 3-Dec & Her Next Friend & Disaster Casual & Antipoison Records & Low \\
\hline 3-Dec & Sara Lov & The Young Eyes EP & Nettwerk & drawer \\
\hline 3-Dec & Lohio & History, the Destroyer & none & Add-High \\
\hline 3-Dec & StereoFidelics & Only Sleeping & none & drawer \\
\hline 3-Dec & Tallest Man on Earth & Shallow Grave & Terrorbird & drawer \\
\hline 3-Dec & Sheepdogs & Big Stand & Tinderbox & drawer \\
\hline 3-Dec & Parlotones & A World Next Door to Yours & Tinderbox & drawer \\
\hline 3-Dec & Maroon 5 & Call and Response & Universal & \\
\hline 5-Dec & Wild Beasts & Limbo, Panto & Domino & Add-High \\
\hline 5-Dec & Geographer & Innocent Ghosts & none & drawer \\
\hline 5-Dec & $\begin{array}{l}\text { The Televangelist and the } \\
\text { Architect }\end{array}$ & $\begin{array}{l}\text { There's a Song in There } \\
\text { Somewhere }\end{array}$ & none & Med \\
\hline 5-Dec & Radio Soulwax & $\begin{array}{l}\text { Part of the Weekend Never } \\
\text { Dies }\end{array}$ & Spectre & Med \\
\hline 5-Dec & Chairlift & Does You Inspire You & Terrorbird & High \\
\hline 5-Dec & Only MakeBelieve & $\begin{array}{l}\text { Message from a } \\
\text { Mockingbird }\end{array}$ & Tinderbox & Add-Med \\
\hline 5-Dec & Mike Falzone & Fun with Honesty & Tinderbox & drawer \\
\hline 8-Dec & Takeover UK & Running with the Wasters & Ryko & Low \\
\hline 8-Dec & Flight 409 & We Don't Dance & Tinderbox & Add-Low \\
\hline 8-Dec & Fire on Fire & The Orchard & Young God Records & Low \\
\hline 9-Dec & King Easy & Radio Sampler Volume 4 & none & \\
\hline 9-Dec & Handsome Deville & Greatest Hits & Tinderbox & \\
\hline 9-Dec & John Meyer & Silver Bullets Don't Work on & Tinderbox & drawer \\
\hline
\end{tabular}




\begin{tabular}{|l|l|l|l|l|} 
& & & \\
\hline 9-Dec & Common & Uullets & pass \\
\hline
\end{tabular}


Appendix 3: WLUR, Records Received/Inclusion Data, 11/15-12/15/08

\begin{tabular}{|c|c|c|c|c|}
\hline $\begin{array}{l}\text { Date } \\
\text { Rec'd. }\end{array}$ & Artist & Album & Promoter & Location \\
\hline \multirow[t]{6}{*}{ 17-Nov } & Todd Hannigen & Vol. 2 Courtside & Planetary & Add \\
\hline & Spit Hot Fire & Spit Hot Fire & Tinderbox & \\
\hline & Rosie Thomas & A Verry Rose Christmas! & Nettwerk & Add \\
\hline & The River Radi & The River Raid & Tinderbox & \\
\hline & Max Tundra & $\begin{array}{l}\text { Parrallax Error Beholds } \\
\text { You }\end{array}$ & Domino & $\begin{array}{l}\text { Add Top } 5 \\
\text { CMJ }\end{array}$ \\
\hline & Belle \& Sebastian & BBC Sessions & None & Add Hot \\
\hline \multirow[t]{10}{*}{ 20-Nov } & Andy Yorke & Simple & 1 Up PR & \\
\hline & David Rubin & One Day & Satellite & \\
\hline & Rivers Cuomo & Alone II & Universal & Add \\
\hline & HeartsRevolution & Switchblade EP & AAM & Add \\
\hline & Totally Michael & Totally Michael & AAM & Add \\
\hline & Collide & Two-Headed Monster & Apples \& Cats & \\
\hline & The Racounturs & Consolors of the Lonely & Warner Bros. & Add \\
\hline & Between the Pine & Friends, Foes, Kith and Kin & Terrorbird & Add \\
\hline & Stereophonics & Decade in the Sun & Syndicate & Add \\
\hline & The Bodies Obtained & From the Top of My Tree & Syndicate & Add \\
\hline \multirow[t]{3}{*}{ 22-Nov } & The Rockwells & Place and Time & None & \\
\hline & Kanye West & 808s and Heartbreak & Universal & Add \\
\hline & Yoome & The Boredom of Me & Nice PR & \\
\hline \multirow[t]{10}{*}{ 24-Nov } & Hush Arbors & Hush Arbors & Terrorbird & $\begin{array}{l}\text { Add Top } 5 \\
\text { CMJ }\end{array}$ \\
\hline & Pretend You're Happy & Pretend You're Happy & Terrorbird & Add \\
\hline & Andige Sessions & Andige Sessions & Syndicate & \\
\hline & Magnolia Sons & Jails Everywhere & Self Promoted & Add \\
\hline & Collide & Two Headed Monster & Noiseplus & \\
\hline & Anjulie & Boom EP & Spectre & Add \\
\hline & Death Cab For Cutie & Something About Airplanes & Spectre & Add \\
\hline & Reefer & Reefer & Terrorbird & $\begin{array}{l}\text { Add Top } 5 \\
\text { CMJ }\end{array}$ \\
\hline & Drag Hoops & Into the Red & SlowBurn & \\
\hline & Bionic & Black Blood & AAM & Add \\
\hline \multirow[t]{9}{*}{ 1-Dec } & Chairlift & Does You Inspire You & Terrorbird & $\begin{array}{l}\text { Add Top } 5 \\
\text { CMJ }\end{array}$ \\
\hline & Soulwax & $\begin{array}{l}\text { Part of the Weekend Never } \\
\text { Dies }\end{array}$ & Spectre & Add \\
\hline & Tallest Man on Earth & Shallow Grave & Terrorbird & Add \\
\hline & David Byrne \& Brian Eno & Everything that Happens... & Team Clermont & Add \\
\hline & Leo Blais & Slow Drivin' EP & Pirate & \\
\hline & Los Campesinos! & We Are Beautiful & Pirate & Add \\
\hline & Lukestar & Lake Toben & Pirate & Add \\
\hline & The Organ & Theives EP & Pirate & Add \\
\hline & JP Hue & The Dear John Letters & Tinderbox & Add \\
\hline \multirow[t]{3}{*}{ 4-Dec } & Sara Lov & The Young Eyes EP & Nettwerk & \\
\hline & John Mayer & Silver Bullets Don't Work.... & Tinderbox & Add \\
\hline & Peter Karis & Change & Tinderbox & \\
\hline
\end{tabular}




\begin{tabular}{|l|l|l|l|l|} 
& Message From a & Tinderbox & \\
\hline & Mnly Mahebliew & Reckingbird & None & \\
\hline & Huma Adut Band & Retrospective I & Universal & Add \\
\hline & Franz Ferdinard & Ulyssesus & None & \\
\hline Platform I Underground & Rush & None & Add \\
\hline & Various & Caddilac Records & Universal & Add \\
\hline Common & Universal Mind Control & AAM & \\
\hline Maroon 5 & Remix Album & AAM & Add \\
\hline & See Sick & S/ & AAM & Add \\
\hline The Younger Sister & The Lady Wins Again & Planetary & Add \\
\hline & The Kindered Kind & EP & AAM & Add \\
\hline
\end{tabular}




\section{Appendix 4: Music Director Interview Questions}

- What does college radio mean to you?

- How does your station uphold those views?

- What sets college radio apart from commercial radio?

- Describe your music selection process.

- How do you view your role as music director?

- How would you describe the music that 'fits' your station?

- How would you describe the music that doesn't 'fit' your station?

- What qualities do you look for in a record to add to the playlist?

- Do you take into account the tastes of others at your station when selecting music?

- Do you take into account media coverage when selecting music?

- Describe your relationship with record promoters.

- Are they an important part of your job?

- Do you ever put something in rotation that you don't like in order to appease them?

- What influence would you say that promoters have on your decision making process?

- Do promoters ever attempt to change your mind about a certain record?

- Could you do your job without the record promoters?

- Would it be easier or harder without them?

- Who do you think needs whom more?

- Do you think they take your stations tastes into account when promoting records?

- How do you think they view you? 


\title{
Appendix 5: Cover Letter for Data Collection Packet
}

DATE

\author{
Aaron Hawley \\ 307-1 Maple Ave. \\ Morgantown, WV 26501 \\ Aaron_J_Hawley@yahoo.com
}

(304)3191-1421

Mr. Music Director

Address

Address

Address

Dear

First of all, thank you for agreeing to assist with the data collection for this project. College radio is very close to my heart, as I'm sure it is for you, and my hopes are that this project will help us glean additional information about how this industry operates.

I am very grateful for your assistance in this matter.

Please begin logging all releases you receive on/after Saturday November $15^{\text {th }}$. All releases received between that date and December $15^{\text {th }}$ should be included. For the purpose of this project we are only tracking albums received by the station between those two dates. You will see that the attached data collection packet consists of five columns. To avoid any confusion, here's the information that should be included in each column.

- Date: This refers to the date received by you, as music director. If you open your mail during your office hours this date is fine. No need to account for the date it arrived in the mail. It is not considered received until opened by you.

- Artist: The artist's name.

- Album: The album title. For those albums with obnoxiously long titles, feel free to abbreviate as long I can figure out which release it is. If it was the 1995 Smashing Pumpkins record it could be listed as either "Mellon Collie..." or "MATIS"

- Promoter: Which record promoter is working this record, AAM, Terrorbird, etc. If you receive a record that is not being worked by a record promoter just write "none" or " $\mathrm{n} / \mathrm{a}$ ".

- Playlist Information: If you do not add this release to your station's playlist leave this blank. If you do add this release simply write "Add". If you use a tiered rotation system, please note where this release was added as well, such as "Add-Hots" or "Add-Lights".

I am eternally grateful for your participation in this project. Feel free to contact me with any and all questions and concerns at the contact information above. I will touch base a couple of times throughout the collection process to make sure everything is going okay.

Sincerely, Aaron Hawley 


\section{Bibliography}

Ahlkvist, J.A. (1999). Music and cultural analysis in the classroom: Introducing sociology through heavy metal. Teaching Sociology, Vol. 27, No. 2, 126144.

Ballinger, J. \& Reese, S.D. (2001). The Roots of a sociology of news: remembering Mr. Gates and social control in the newsroom. Journalism \& Mass Communication Quarterly, Vol. 78 Issue 4, 641-658.

Cohen, H.G. (2004). The Marketing of Duke Ellington: Setting the strategy for an African American maestro. The Journal of African American History, Vol. 89 No. 4, 291-315.

Cohen, Norm (2005). The Forget Me Not Songsters and their role in the American folksong tradition. American Music, Vol. 23, No. 2, 137-219.

Conway, Daniel. (Personal Interview, January $18^{\text {th }}, 2009$ )

Desztich, Rachael \& McClung, Steven. (2007). Indie to an extent? Why music gets added to college radio playlists. Journal of Radio Studies, Vol. 14 Issue 2, 196-211.

Fader, P.S. et al. (2005). RFM and CLV: Using Iso-Value curves for customer base analysis. Journal of Marketing Research, Vol. 42 No. 4, 415-430.

Geller, Valerie (1996). Creating Powerful Radio. New York: M Street Publications.

Gracyk, T.A. (1993). Romanticizing rock music. Journal of Aesthetic Education, Vol. 27, No. 2, 43-58.

Hakanen, E.A. (1998). Counting down to number one: The Evolution of the meaning of popular music charts. Popular Music, Vol. 17, No. 1, 95-111.

Hesmondhalgh, David (1997). Post-Punk's attempt to democratise the music industry: The success and failure of Rough Trade. Popular Music, Vol. 16, No. 3, 255274.

Lee, Stephen (1995). Re-examining the concept of the 'independent' record company: The Case of Wax Trax! Records. Popular Music, Vol. 14, No. 1, 13-31.

Lopes, P.D. (1992). Innovation and diversity in the popular music industry, 1969-1990. American Sociological Review, Vol. 57, No. 1, 56-71.

McClung, Steven. (2001). College radio station web sites: Perceptions of value and use. Journalism \& Mass Communication Educator, Vol. 56 Issue 1, 62-73. 
McLeod, Kembrew (2001). 'Star and a half': A critique of rock criticism in North America. Popular Music, Vol. 20, No. 1, 47-60.

Miller, Nathan. (Personal Interview, April 10 ${ }^{\text {th }}, 2008$ )

Moe, W.W. \& Fader, P.S. (2001). Modeling hedonic portfolio products: A Joint segmentation analysis of music compact disc sales. Journal of Marketing Research, Vol. 38, No. 3, 376-385.

Morella, Michael. Personal Interview, February $10^{\text {th }}, 2009$ )

Negus, Keith. (1993). Plugging and programming: Pop radio and record promotion in Britain and the United States. Popular Music, Vol. 12, No. 1, 57-68.

Novak, Jesse. (Personal Interview, April 15 ${ }^{\text {th }}, 2008$ )

Novak, Jesse. (Personal Interview, January $22^{\text {nd }}, 2009$ )

Richardson, J.W. \& Scott, Kim A. (2002). Rap music and its violent progeny: America's culture of violence in context. The Journal of Negro Education, Vol. 71, No. 3, 175-192.

Shoemaker, Pamela et al. (2001). Individual and routine forces in gatekeeping. Journalism \& Mass Communication Quarterly, Vol. 78 Issue 2, 233-246.

Sofsky, Rupam. (Personal Interview, April 15 ${ }^{\text {th }}, 2008$ )

Sofsky, Rupam. (Personal Interview, January $17^{\text {th }}, 2009$ )

Tantillo, Emily. (Personal Interview, February $12^{\text {th }}, 2009$ )

Tremblay, R.W. (2003). A Delphi study on the future of college radio. Journal of Radio Studies, Vol. 10 Issue 2, 170-185.

Wald, Gayle (1998). Just a girl? rock music, feminsim and the cultural construction of female youth. Signs, Vol. 23, No. 3, 585-610.

Walker, Jesse (2001). Rebels on the Air: An Alternative History of Radio. New York: New York University Press.

Wall, Tim. (2007). Finding an alternative: Music programming in US college radio. Radio Journal: International Studies in Broadcast \& Audio Media, Vol. 5 Issue 1, 35-54.

Wehrle, Robert. (Personal Interview, April $18^{\text {th }}, 2008$ ) 
WLUR. (2008) About Us. http://wlur.wlu.edu/newWLURaboutus.htm

Willis, Susan (1993). Hardcore: Subculture American style. Critical Inquiry, Vol. 19, No. 2, 365-383.

WPTS-FM. (2008) About. http://www.wpts.pitt.edu/?do=about

Wright, Robert. (2000). 'I'd sell you suicide': Pop music and moral panic in the age of Marilyn Manson. Popular Music, Vol. 19, No. 3, 365-385.

WWVU-FM, The New Music Pioneer. http://u92.wvu.edu 